\title{
Capítulo 3 - Publicações de Müller nos archivos
}

\author{
Flavia Pacheco Alves de Souza
}

\section{SciELO Books / SciELO Livros / SciELO Libros}

SOUZA, F. P. A. Publicações de Müller nos archivos. In: Notas de um naturalista do sul do Brasil: Fritz Müller: história da ciência e contribuições para a biologia [online]. São Bernardo do Campo, SP:

Editora UFABC, 2017, pp. 89-167. ISBN 978-85-68576-80-9.

https://doi.org/10.7476/9788568576809.0005.

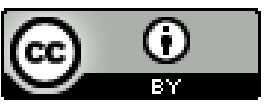

All the contents of this work, except where otherwise noted, is licensed under a Creative Commons Attribution 4.0 International license.

Todo o conteúdo deste trabalho, exceto quando houver ressalva, é publicado sob a licença Creative Commons Atribição $\underline{4.0}$.

Todo el contenido de esta obra, excepto donde se indique lo contrario, está bajo licencia de la licencia $\underline{\text { Creative }}$ Commons Reconocimento 4.0. 


\section{PUBLICAÇÕES DEMÜLLER NOS ARCHIVOS}

Neste capítulo serão analisados os trabalhos publicados por Müller no periódico Archivos do Museu Nacional do Rio de Janeiro, distribuídos entre os volumes II (1877) ao VIII (1892). Suas publicaçóes tratam, de forma geral, de assuntos concernentes à zoologia dos invertebrados. Como o autor náo tinha um grupo específico de pesquisa, optou-se em dividir este capítulo sob o ponto de vista biológico, conforme os tópicos de seu interesse em quatro grandes eixos: lepidópteros, tricópteros, dípteros e crustáceos. Dentro de cada um destes eixos de estudos, há uma diversidade de temas tratados, como metamorfose, taxonomia, proposição de novas espécies e gêneros, descrição de estruturas e órgãos, relação entre animais e plantas, etc. Em cada uma dessas categorias, discutir-se-á o diálogo estabelecido entre Müller e Darwin, bem como as referências a outros autores do período.

Acredita-se que a minuciosidade de observaçōes, típica dos trabalhos de Müller, remete à sua formação universitária em filosofia e em medicina, que lhe ofereceu conhecimento técnico em matemática e em ciências naturais; diferente de Darwin, que não possuía uma formação específica em ciências e pode ser considerado um autodidata no campo que escolheu para pesquisar. Müller preocupava-se prioritariamente em estudar os organismos vivos e suas inter-relaçôes na natureza, fato que pode ser caracterizado como atitude intelectual do cientista moderno, sobretudo 
do que viria a se configurar como postura dos biólogos nos séculos XX e XXI.

A maioria de seus artigos é acompanhada de figuras, visto que Müller era um exímio desenhista, elogiado até mesmo por Darwin (ZILLIG, 1997, p. 93). Convém ressaltar que as ilustraçôes já eram utilizadas como ferramenta no campo das ciências naturais desde o período das grandes navegaçóes (século XV), em que, além das riquezas naturais trazidas do Novo Mundo, circulavam também aquelas redigidas por pessoal contratado para tal fim.

Papavero e Martins (1994) atribuem à Flore française (1778), de Lamarck, a primeira utilização das ilustraçôes como ferramenta científica; no caso específico, para estabelecimento de chaves dicotômicas para as plantas. A partir do século XVIII, tais figuras buscavam retratar o objeto de estudo de forma extremamente fiel, respeitando as medidas, proporçóes e contrastes, auxiliando o leitor a realizar comparaçóes com outros exemplares, bem como fornecer, por exemplo, a proposiçáa de um novo gênero ou espécie. No entanto, há inúmeros estudos que tratam das ilustraçôes como documentos históricos que não retratam de forma neutra e fiel a natureza, mas que também são construçōes científicas, artísticas e intelectuais próprias do tempo e do modo de pensar e de viver dos sujeitos que as elaboraram, atravessadas por subjetividades dos seus olhares e materializadas pelos aparatos técnicos e tecnológicos disponíveis em seu tempo. Ou seja, a natureza, mais do que retratada, também é pensada pelas imagens, constituindo-se em discurso poderoso, ao mesmo tempo, subjetivo e objetivo, científico tanto quanto artístico, afeito ao imaginário de uma época (SANTOS; RIBEIRO, 2008).

Apesar de o Museu Nacional contar com um desenhista no período em que Müller atuara ${ }^{41}$, as figuras originais eram forneci-

\footnotetext{
41 De 1876 a 1879, quem ocupava este cargo era o engenheiro Teodoro Fernandes Sampaio (1855-1977), sucedido por seu ajudante Antônio Avé Lallemant
} 
das pelo próprio naturalista, que buscava retratar seus exemplares de estudo em diferentes posiçóes, fornecendo medidas, bem como ampliaçóes de partes específicas do corpo do animal (quando necessário). Além disso, ele utilizou ilustraçôes de naturalistas contemporâneos a ele como material de referência para seus estudos, buscando dessa forma comparar seus "achados" de Santa Catarina com organismos já classificados e ilustrados, oriundos de diversas partes do mundo. Nesse sentido, as figuras dos trabalhos passam de "simples desenhos" para documentos que auxiliavam os pesquisadores do período, tal qual o escrito.

Sempre que possível, buscou-se atualizar os nomes científicos das espécies estudadas através de consulta à literatura especializada, bem como fornecer (quando se encontrou) dados relevantes sobre outras pesquisas referentes ao mesmo objeto de estudo, posteriormente realizados.

Todavia, faz-se necessário descrever o que se entendia como espécie no século XIX, visto que no período em que Darwin escreveu Origin ainda não havia um consenso sobre a definição do termo.

Para Carl Linnaeus (1707-1788) no século XVIII, por exemplo, espécie era entendida como um conceito tipológico; isto é, uma entidade que difere pelas características observáveis (macroscópicas). Tal conceito atualmente é raramente utilizado, visto que ele força os seus adeptos a considerarem espécie até mesmo as variaçóes que ocorrem dentro de uma mesma população, apenas por um caractere distintivo.

Para os nominalistas do século XIX, as espécies eram construçôes mentais arbitrárias; conceito igualmente inválido na

(LOPES, 2009, p. 182). De acordo com Agostinho (2014, p. 52), o diretor Ladislau Neto considerava que a ilustração era uma das dificuldades para a impressão dos Archivos, visto que havia atrasos na confecção destas, bem como faltavam profissionais especializados para o serviço. 
atualidade, visto que representantes de culturas diferentes delimitam espécies com atributos semelhantes.

Darwin aderiu ao conceito biológico de espécie, apesar de o termo muitas vezes apresentar confusóes, principalmente em se tratando de variedades de plantas, conforme estudo realizado por Mayr (2006, p. 29). O conceito biológico de espécie refere-se ao consenso baseado nas observaçôes dos naturalistas: em uma dada localidade, populaçóes de espécies diferentes coexistem, mas não cruzam entre si.

Este conceito é observado nos trabalhos da maioria dos naturalistas e evolucionistas do século XIX e também perdura entre os biólogos modernos, apesar de que o conceito tipológico ainda tenha certa legitimidade em algumas áreas de pesquisa.

Para Müller, as espécies eram vistas sob o ponto de vista biológico de forma que este conceito perdurará na análise de suas publicaçôes.

\subsection{Estudos sobre lepidópteros}

Analisando a produção científica de Müller, organizada em 264 publicaçôes (SCHLENZ, FONTES, HAGEN, 2012, p. 4861), nota-se que sobre os lepidópteros (Quadro 4), o autor publicou 37 trabalhos em diversas vertentes: morfologia de espécies, relação entre flores e borboletas, função dos órgãos odoríferos, máculas sexuais e mimetismo. Muitas dessas publicaçôes foram submetidas a revistas estrangeiras e importantes à época, como Nature (Reino Unido) e Kosmos (Alemanha), através de trechos das cartas que Müller endereçava a Darwin ou a seu irmáo Hermann; outras foram comunicadas em encontros científicos por pesquisadores e publicadas nos anais das respectivas Sociedades. 
Quadro 4 - Principais características da ordem Lepidoptera

\begin{tabular}{|c|c|c|}
\hline $\begin{array}{l}\text { Etimologia: } \\
\text { lepis ou lépidos } \\
\text { significa escamas } \\
\text { e pteron, asa. A } \\
\text { referência ao nome } \\
\text { é a característica } \\
\text { principal da família, } \\
\text { em que as asas } \\
\text { sáo revestidas por } \\
\text { escamas }\end{array}$ & $\begin{array}{l}\text { São insetos holometábolos, } \\
\text { com dois pares de asas } \\
\text { membranosas, corpo e } \\
\text { demais apêndices revestidos } \\
\text { por escamas. Apresentam } \\
\text { peças bucais (probóscide) } \\
\text { do tipo sugador. Os hábitos } \\
\text { alimentares dos adultos são } \\
\text { distintos das larvas, visto que } \\
\text { estas possuem peças bucais } \\
\text { mastigadoras. }\end{array}$ & $\begin{array}{l}\text { Os adultos se } \\
\text { alimentam de néctar } \\
\text { e pólen; há também } \\
\text { os que se alimentam } \\
\text { de líquidos de frutos } \\
\text { fermentados, os } \\
\text { que visitam excretas } \\
\text { animais ou resinas } \\
\text { vegetais e os que se } \\
\text { alimentam de sangue. }\end{array}$ \\
\hline
\end{tabular}

Fonte: RAFAEL et al. (2012, p. 625-627).

A Ordem Lepidoptera inclui as mariposas e borboletas. A distinção entre borboletas e mariposas se baseia em uma série de diferenças observáveis: borboletas (Lepidoptera, Rhopalocera) são insetos diurnos, geralmente com cores vivas e que possuem as asas elevadas em relação ao corpo; já as mariposas (Lepidoptera, Heterocera) são noturnas, em geral pouco coloridas e mantêm as asas sempre abertas. No Brasil, são conhecidas quase $26 \mathrm{mil}$ espécies de lepidópteros (RAFAEL et al., 2012, p. 625).

O desenvolvimento dos lepidópteros é do tipo holometábolo ou metamorfose completa. Após a eclosão do ovo, emerge uma larva vermiforme sem nenhuma semelhança com o indivíduo adulto (também chamada de imago), que passa por diversas modificaçôes (instares larvais) até se transformar em pupa; estágio no qual ocorre a formação das asas externas e dos órgãos sexuais. Todo o estágio de metamorfose é controlado e balanceado pelos hormônios ecdisteróides e juvenil, secretados pelas glândulas protorácicas e pelos corpora allata (par de estruturas glandulares associadas ao cérebro). Como a liberação dos hormônios é controlada, cada estágio do desenvolvimento é preciso (THUMMELL, 1995): quando a ecdisona inicia a muda em 
estágio inicial larval, a concentração de hormônio juvenil na hemolinfa (fluído corporal) é alta, para garantir as séries instares que a larva sofre. No último estágio larval, o hormônio juvenil secretado pelos corpora allata é cessado, o que garante a mudança de larva para pupa. Quando a pupa está pronta para o próximo estágio (imago), o hormônio juvenil já se encontra totalmente ausente na hemolinfa, garantindo a mudança de pupa para adulto (BRUSCA; BRUSCA, 2007, p. 653-656).

Uma das maiores contribuiçôes de Müller neste campo de pesquisa foi a proposição de um mimetismo em borboletas, posteriormente nomeado como mimetismo mülleriano. A palavra mimetismo deriva do grego mimetés, cujo significado é imitador. É utilizada na biologia para explicar a evolução convergente na aparência de dois organismos distintos como mecanismo de defesa, geralmente para confundir predadores.

Sua pesquisa sobre mimetismo foi originalmente publicada na revista Kosmos (1879) sob o título de: Ituna und Thyridia. Ein merkwürdiges Beispiel von Mimicry bei Schmetterlingen (Ituna e Thyridia. Um exemplo notável de mimetismo em borboletas) e comunicada pelo Dr. Raphael Meldola (1849-1915) no mesmo ano à Sociedade Entomológica de Londres.

Este mimetismo também foi observado por Müller em dois outros gêneros de borboletas, Eueides, Hübner (Nymphalidae, Heliconiini) e Acraea, Hübner (atual Actinote) (Nymphalidae, Acraeinae), também em 1879. Esta observação para estes dois gêneros foi comunicada no dia 05 de fevereiro de 1879, na Sociedade Entomológica de Londres também pelo Dr. Raphael Meldola e posteriormente publicada nos Anais da Reunião do ano corrente, sob o título de On a remarkable case of mimicry of Eueides pavana with Acraea thalia (Um caso notável de mimetismo entre Eueides pavana e Acraea thalia) (MÜLLER, 1879). 
Até a proposição do mimetismo mülleriano, o único tipo de mimetismo conhecido era o proposto por Henry Walter Bates (1825-1892) em 1862. Bates ficou 11 anos no Brasil, parte destes, acompanhado por Alfred Russel Wallace (1823-1913), coletando material zoológico e botânico para o Museu de História Natural de Londres. Este mimetismo, denominado posteriormente de mimetismo batesiano, baseou-se em dados coletados pelo autor em suas viagens à Região Amazônica, nas quais observou duas espécies de borboletas distintas que possuíam padrões de coloração semelhantes. Heliconiidae Swainson, 1822 possuía odor e gosto desagradável aos predadores (pássaros) que as evitavam, enquanto Pieridae Duponchel, 1835 não possuía estes atributos, mas também era evitada devido à semelhança de coloração entre as espécies. Bates nomeou Heliconiidae como modelo e Pieridae como mímico. Para ele, a semelhança entre ambas as borboletas poderia ser explicada pelo mecanismo da seleção natural de Darwin: borboletas mais proximamente parecidas com o modelo (de gosto e odor desagradável) eram protegidas, enquanto aquelas que se diferenciavam do modelo eram gradativamente eliminadas.

O mimetismo proposto por Müller difere daquele proposto por Bates, principalmente porque as espécies que compartilham o mesmo sinal (aparência) se beneficiam mutuamente, já que isto reforça o aprendizado dos predadores. Já no mimetismo batesiano uma das espécies (o mímico) sinaliza ser tóxica sem de fato o ser, agindo como um parasita (ou ruído) do sinal da espécie imitada (modelo). O esquema a seguir compara os dois modelos: 

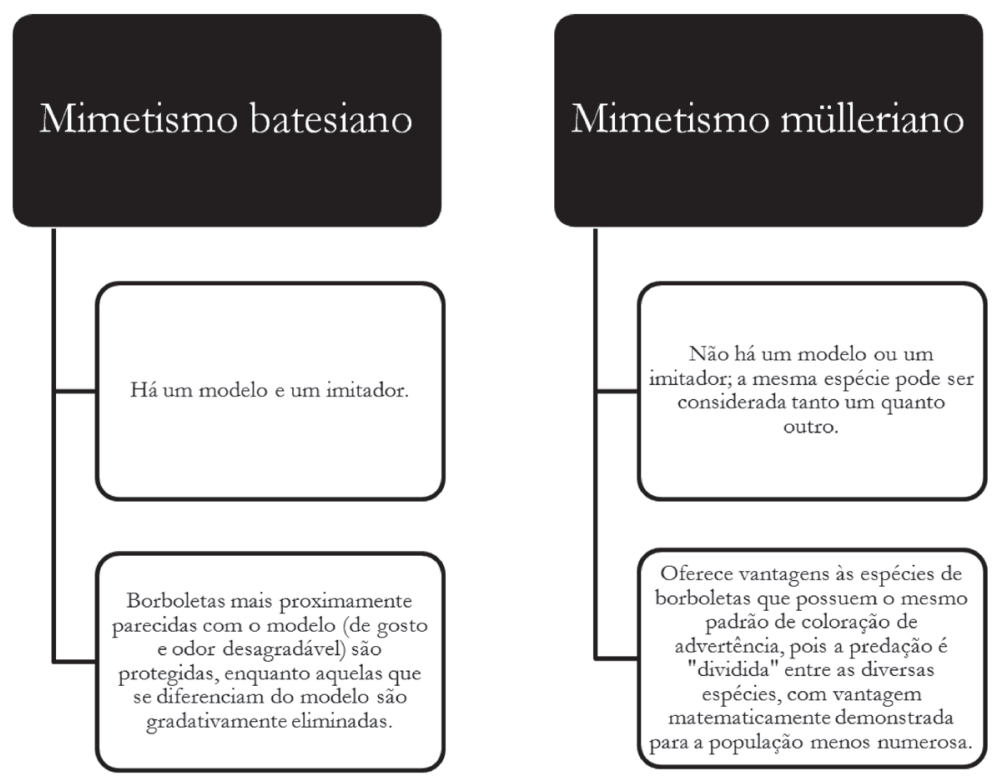

Fonte: A Autora.

Nesse tipo de mimetismo, Müller observou que tanto as borboletas do gênero Ituna Walker, 1854 quanto as Thyridia Hübner, 1816 são impalatáveis a predadores, pois compartilham o mesmo padrão de coloração de advertência, reforçando a proteção de ambas contra predadores, conforme o excerto a seguir:

Estes dois gêneros sempre foram considerados, e ainda são reconhecidos como gênero aliados. Sua semelhança, no entanto, não é devido à consanguinidade, mas sim por meio da imitação notável; na medida em que estes insetos têm não só colecionadores casuais enganados, mas também, após uma cuidadosa comparação, observadores qualificados. A semelhança destes gêneros é o mais digno de nota, uma vez que ocorre entre insetos, ambos pertencentes ao grupo de borboletas, que são protegidas por um desgosto em plenitude. A explicação que se aplica é um notável caso de mimetismo. (MÜLLER 1879, p. XX). 
A este artigo de Müller, também se atribui, na bibliografia, o primeiro modelo de proposição matemática de um tema ecológico sob perspectiva darwiniana (FONTES, HAGEN, 2009; WEST, 2009). O fato é que o autor demonstra, através de cálculos matemáticos, a vantagem para a espécie mais rara de possuir tal mimetismo, conforme o excerto a seguir:

Sendo $a_{1}$ e $a_{2}$ os números de indivíduos de duas espécies de borboletas náo comestíveis numa determinada área durante um verão, e sendo $n$ o número de borboletas de uma espécie bem diferente, que é consumida durante o verão até a sua não comestibilidade ser bem amplamente conhecida. Se as duas espécies fossem bem diferentes, cada espécie perderia $n$ indivíduos. Se ao contrário elas forem indistinguivelmente semelhantes, a primeira perderia $\mathrm{a}_{1} \mathrm{n} / \mathrm{a}_{1}+\mathrm{a}_{2}$ e a segunda $\mathrm{a}_{2} \mathrm{n} /$ $\mathrm{a}_{1}+\mathrm{a}_{2}$. Esse ganho absoluto devido à semelhança seria para a primeira espécie $n--a_{1} n / a_{1}+a_{2}=a_{2} n / a_{1}+a_{2}$; e assim também para a segunda, $a_{1} n / a_{1}+a_{2}$. Esse ganho absoluto, comparado com a frequência da espécie, dá para a primeira espécie $\mathrm{g}_{1}=\mathrm{a}_{2} \mathrm{n} / \mathrm{a}_{1}\left(\mathrm{a}_{1}+\mathrm{a}_{2}\right)$, e para a segunda, $\mathrm{g}_{2}=\mathrm{a}_{1} \mathrm{n} / \mathrm{a} 2\left(\mathrm{a}_{1}+\mathrm{a}_{2}\right)$, do que resulta, $g_{1}: g_{2}=a 2_{2}: a 1_{2}$ (MÜLLER, 1878 apud FONTE, HAGEN, 2009, p. 42).

O que Müller busca evidenciar com esta proposição é que tal mimetismo oferece vantagens às espécies de borboletas que possuem o mesmo padrão de coloração de advertência, pois a predação é "dividida" entre as diversas espécies, com vantagem matematicamente demonstrada para a população menos numerosa, que sofrerá menor perda de indivíduos. Como West (2009) bem exemplifica,

[...] se tivéssemos cinco mil indivíduos de uma espécie e mil de outra voando juntas e que pássaros locais matassem cem de cada espécie durante a estaçáo enquanto aprendiam 
quais eram as desagradáveis. $\mathrm{O}$ risco de predação da espécie mais rara seria $100 / 1.000=10 \%$, enquanto na espécie mais comum seria $100 / 5.000=$ somente a $2 \%$. Daí, qualquer variante da espécie mais rara que se assemelhasse à mais comum teria um risco reduzido de ser morto por um predador ingênuo e a seleçáo natural aumentaria a frequência daquela variante.

No período em que trabalhou no Museu (1876-1891), Müller foi o único naturalista que publicou sobre lepidópteros, com exceçấo do artigo Insectologia, Lepidopteros, de Nicolau Moreira (1824-1894), no volume IV (1879), com 12 páginas sobre a descrição morfológica de uma espécie de Heliconia (MOREIRA, 1879).

Sobre lepidópteros, há nas correspondências trocadas entre Darwin e Müller quatro referências sobre o assunto (ZILLIG, 1997, p. 187; 192; 206; 211). Müller chegou a enviar uma probóscide de $22 \mathrm{~cm}$ de uma mariposa, coletada em Santa Catarina, para o amigo examinar.

\subsubsection{Relação entre plantas e borboletas}

O termo versicolor era utilizado na época às plantas cujas flores mudavam de cor durante o mesmo período de floração. Müller também utilizou o adjetivo "pronubo", que significa noivo ou prestes a se casar, para descrever de forma poética a relaçáo de polinização dos insetos nas flores.

Em seu primeiro trabalho publicado nos Archivos (A correlação das flores versicolores e dos insectos pronubos), Müller descreve a relação existente entre insetos polinizadores (visitantes, como os denomina) com plantas que mudam de cor durante o mesmo período de floração, estudo já realizado por seu contemporâneo Frederico Delpino, que trabalhava na 
Universidade de Genova com o mesmo tema. Müller conhecia estes trabalhos, provavelmente por ter tido acesso aos livros desse autor enviados ao Brasil por algum amigo correspondente da Europa, o que era uma prática frequente. Ele se utiliza dos trabalhos de Delpino (Ulteriori osservazioni e considerazioni sulla Dicogamia nel Regno Vegetale, publicado em dois volumes - 1868 e 1870) que descrevem a relação existente entre abelhas que polinizam as flores de Ribes aureum Pursh (família Grossulariaceae) e de Caragana arborescens Lam. (Família Fabaceae). Delpino observou que ambas as plantas, em um mesmo período de floração, mudavam a coloraçáo de suas flores de tons amarelos para laranjas e que os insetos polinizadores dessas duas espécies de plantas demonstravam predileção apenas pelas flores amarelas, o que o levou a concluir que a variação das cores poderia estar correlacionada aos insetos que as visitavam, como se houvesse um "momento propício para uma visita eficaz" nas flores:

Eu estudei o fenômeno em Ribes aureum, em Caragana arborescens e em Phaseolus caracalla ${ }^{42}$. As flores destas e de muitas outras plantas que não posso mencionar por razóes de brevidade, nos últimos dias de floraçáo mudavam suas cores de amarelo para alaranjado (Ribes e Caragana) e de roxo para amarelo (Phaseolus caracalla). Visitantes normais, como os Anthophora pilipes ${ }^{43}$ nas flores de Ribes, vários apídeos nas flores de Caragana, Xylocopa violacea nas flores de Caracalla, abelhas e Anthidium de outras espécies, sabiam bem distinguir as duas cores e reservavam suas visitas às flores da primeira etapa, cheias de pólen e mel, esquivando-se da etapa seguinte que já estava sem alimento (DELPINO, 1996, p. 136).

${ }^{42}$ Cochliasanthus caracalla L.

43 Apis pilipes Fabricius. 
Além do conhecimento dos trabalhos de Delpino, Müller utiliza outras referências em seu trabalho, exemplo do excerto em que comenta a falta de estudos à época sobre o tema em questão:

Muito escassas são até agora as observaçóes que possam elucidar a significação biológica das flores versicolores ou de cor mudável.

Ainda hoje, como, há perto de um século disse Brotero, a cor das corolas ${ }^{44}$ é ordinariamente desprezada pelos botânicos modernos. Há compêndios de botânica, aliás excelentes, que nem uma linha dedicam à cor das flores (MÜLLER, 1877a, p. 19).

É possível notar neste excerto, grande preocupação do autor em oferecer ao seu leitor credibilidade científica acerca de sua pesquisa. Para buscar atingir essa credibilidade, Müller lança mão de citações de autores "renomados"; além de Delpino, ele se refere a Felix Avellar Brotero (1744-1828), botânico português que publicou em Paris, no ano de 1788, os dois volumes de sua obra intitulada Compêndio de Botânica, única do gênero escrita em português à época. Além de citar o autor, Müller transcreve de forma literal o trecho da obra demonstrando que ele mesmo possuía autoridade e conhecimento sobre o assunto (SOUZA; SANTOS, 2014).

Apesar de Müller apontar a ausência de estudos específicos à época e atribuir a Delpino os referentes à coloração das flores e polinização, é importante ressaltar que muitos dos naturalistas contemporâneos e anteriores a ele já pesquisavam a relaçáo dos insetos com a polinização, como Konrad Sprengel (17501816), que descreveu, com precisão, a polinização por insetos, demonstrando a função da corola nas flores em seu livro Das entdeckte Geheimniss der Natur, im Bau und in der Befruchtung der

\footnotetext{
44 É o envoltório por dentro do cálice da flor. Geralmente é a parte mais vistosa, pois apresenta cores variadas. É constituída por um ou mais segmentos, livres ou concrescidos, chamados pétalas.
} 
Blumen (Os segredos descobertos da natureza na construção e na fertilização das flores) publicado em 1793 (SPRENGEL, 1793); Charles Darwin, em livro publicado em 1862, On the various contrivances by which British and foreign Orchids are fertilised by insects (Sobre os vários artifícios pelas quais as orquídeas britânicas e estrangeiras são fertilizadas por insetos) (DARWIN, 1890); e o próprio irmão de Fritz, Hermann, que publicou em 1872, Die Befruchtung der Blumen durch Insekten und die gegenseitigen Anpassungen beider (A fertilização das flores através dos insetos e a adaptação mútua de ambos).

Pode-se perceber que a pesquisa de Müller está em consonância com a de outros naturalistas do período que se preocupavam com a mesma questão; original por ser realizada no Brasil com observaçáo de flora e fauna nativas, realizada com plantas do gênero Lantana L., polinizadas por borboletas.

No gênero Lantana (família Verbenaceae) são listadas quatro espécies cultiváveis como ornamentais no Brasil (LORENZI; SOUZA, 2008), sendo que as mais comuns sáo Lantana camara L. e Lantana montevidensis Spreng., bem como híbridos das duas. Apesar de o autor não se referir à espécie observada, em nossa pesquisa, é possível inferir que se trata de Lantana camara, que ocorre das Antilhas até o Brasil e que possui algumas das características citadas pelo naturalista, como as flores que mudam de cor na floração e são polinizadas principalmente por borboletas.

No artigo, Müller relata detalhadamente o início da sua observaçáo e os motivos que o levaram a escolher um pequeno arbusto em floração próximo à sua residência, na entấo colônia de Blumenau. A eleiçáo do arbusto baseou-se na comodidade, visto que os capítulos ${ }^{45}$ florais estavam a cerca de 1,5 metro do solo e o trabalho de observação era diário, o que totalizou 24 dias (entre os dias 14 de outubro e 07 de novembro).

\footnotetext{
45 Tipo de inflorescência em que as flores são geralmente sésseis, muito próximas umas das outras e inseridas em um eixo comum, frequentemente alargado (RAVEN, 2014).
} 
Apesar dele náo se referir ao ano de suas observaçóes, tem-se conhecimento de que foram no ano corrente (1877), visto que comenta sobre essa pesquisa com Darwin em carta datada de 27 de novembro de 1877, na qual faz um breve resumo desse trabalho para o amigo, acrescentando:

Estas observaçóes, cujo relato será publicado nos "Archivos do Museu Nacional do Rio de Janeiro", confirmam as observaçóes de Delpino sobre Ribes aureum e Caragana arborescens. $\mathrm{Se}$ as flores durassem apenas um dia, suas cabeças seriam bem menos notáveis; se elas durassem três dias sem mudar de cor, as borboletas perderiam muito tempo visitando flores sem mel, já fertilizadas [...] (ZILLIG, 1997, p. 209).

Em sua observação, Müller notou que as flores de Lantana duravam três dias, sendo que a coloraçáo era amarela no primeiro dia, laranja no segundo e roxa ou purpúrea no terceiro. Quanto ao formato do tubo floral, pressupôs que os possíveis visitantes dessas flores deveriam ser lepidópteros, sendo estes os únicos capazes de, com sua probóscide ${ }^{46}$ delgada e comprida, sugarem o néctar no fundo de semelhante corola. De fato, flores que possuem longo tubo floral geralmente são polinizadas por mariposas e borboletas, visto que o nectário está localizado na base do longo tubo floral, sendo usualmente acessível às longas probóscides sugadoras destes insetos.

Em 24 dias de coleta de dados, Müller constatou a visita de 12 espécies de lepidópteros - distribuídos no quadro a seguir, acrescido de comentários e atualização taxonômica.

46 No original, o termo probóscide, que se refere ao conjunto das peças bucais dos lepidópteros, é denominado em sua forma anterior, a saber: tromba. 
Quadro 5 - Espécies de lepidópteros observados por Müller em arbusto do gênero Lantana, no período de 14 de outubro a 07 de novembro de 1877

\begin{tabular}{|c|c|}
\hline Espécie & Taxonomia atual da espécie e comentários \\
\hline $\begin{array}{l}\text { Danais erippus } \\
\text { Cram. }\end{array}$ & $\begin{array}{l}\text { Atualmente o gênero é Danaus. No original, o termo } \\
\text { aparece grafado como "Danais". A princípio cogitou-se } \\
\text { possibilidade de erro de impressáo, ou mesmo de um } \\
\text { desconhecimento de Müller quanto à grafia correta, } \\
\text { visto que o erro se repete em outro artigo do naturalista, } \\
\text { a saber: As máculas sexuais dos individuos masculinos } \\
\text { das espécies Danais erippus e D. gilippus. Em consulta } \\
\text { à literatura específica da época, principalmente ao } \\
\text { Genera of diurnal lepidoptera, notou-se que o gênero } \\
\text { também foi grafado como Danais (DOUBLEDAY, } \\
\text { WESTWOOD,1856-1860, p. 89); porém é Butler } \\
\text { (1866, p. 43) quem esclarece a dúvida em sua Monography } \\
\text { of the diurnal Lepidoptera belonging to the Genus Danais: } \\
\text { o gênero pode ser grafado como Danaida, Danaus ou } \\
\text { Danais. Esta espécie é denominada atualmente como } \\
\text { Danaus plexippus plexippus L. }\end{array}$ \\
\hline $\begin{array}{l}\text { Heliconius apseudes } \\
\text { Hübn. }\end{array}$ & Atual Heliconius sara apseudes Hübn. \\
\hline Colaenis dido L. & Atual Philaethiria dido L. \\
\hline Colaenis julia Tabr. & Atual Dryas julia Fabr. \\
\hline Dione juno Cram. & Atual Dione juno Cram. \\
\hline $\begin{array}{l}\text { Hesperocharis } \\
\text { anguitea God. }\end{array}$ & $\begin{array}{l}\text { No periódico o nome da espécie está grafado de forma } \\
\text { incorreta: Hesperocharis angustia. }\end{array}$ \\
\hline Eurema leuce Boisd. & Atual Eurema dina leuce Boisd. \\
\hline $\begin{array}{l}\text { Pieris elodia Boisd. } \\
\text { (ou P. aripa Boisd.?) }\end{array}$ & $\begin{array}{l}\text { Atual Leptophobia aripa elodia Boisd. Devido à morfologia } \\
\text { similar de Pieris elodia e Pieris aripa, Müller não soube } \\
\text { expressar com exatidão qual foi a espécie por ele observada } \\
\text { e fornece no artigo ambas as denominaçóes. Ele também } \\
\text { coloca como incerto o autor da descrição de Pieris aripa } \\
\text { (Boisd.?). De fato, a espécie foi descrita em } 1836 \text { por } \\
\text { Jean-Baptiste Alphonse Dechauffour de Boisduval (1799- } \\
\text { 1879), entomologista e botânico francês. }\end{array}$ \\
\hline $\begin{array}{l}\text { Daptonoura lycimnia } \\
\text { Cram. }\end{array}$ & Atual Melete lycimnia Cram. \\
\hline Callidryas apris Tabr. & Atual Phoebis neocypris Tabr. \\
\hline Papilio thoas L. & Atual Papilio thoas L. \\
\hline $\begin{array}{l}\text { Espécie não } \\
\text { identificada }\end{array}$ & $\begin{array}{l}\text { Indivíduo da família das Hesperídeas, não identificado } \\
\text { pelo naturalista. }\end{array}$ \\
\hline
\end{tabular}

Fonte: Dados adaptados de suas coletas (Müller, 1877a, p. 21-22). 
Destas 12 espécies, o autor conseguiu relacionar a polinizaçáo à determinada coloração para 10 delas e cerca de 40 indivíduos, sendo que as mais frequentes foram Heliconius apseudes e Daptonoura lycimnia ${ }^{47}$.

A fim de organizar as informaçôes descritas em seu artigo para cada espécie de lepidóptero e a coloração de flor polinizada, este trabalho opta em transcrever os dados na forma de um quadro, disponibilizado a seguir:

Após observar que a maioria dos indivíduos (28) exibia predileção apenas pelas flores amarelas da Lantana, Müller compara seus resultados com as discussóes de Delpino, em que a cor indica aos insetos as flores que eles devem polinizar, para se aprovisionarem de maior quantidade de néctar ou pólen.

Para Müller, seu estudo com uma espécie diferente de planta e sua correlação com uma outra ordem de insetos polinizadores não só apoiava as consideraçóes de Delpino, de que as flores versicolores precisam e direcionam as "visitas" dos insetos polinizadores para serem fecundadas com maior eficiência, mas o levam a propor duas hipóteses acerca do motivo das borboletas serem levadas a polinizarem somente as flores do primeiro dia (MÜLLLER: $1877 a$, p. 22-23):

$1^{\text {a }}$ - Por algum instinto, hábito hereditário e congênito, é que se evitam as flores alaranjadas e roxas, visitando unicamente as amarelas.

$2^{\mathrm{a}}$ - Cada borboleta aprende por si mesma, pela sua própria experiência, que somente as flores amarelas retribuem com o doce néctar o importante serviço que ela lhes presta, transferindo o pólen de uma flor para o estigma da outra.

\footnotetext{
47 De fato, estas duas espécies são amplamente divulgadas na literatura como polinizadoras específicas de Lantana camara; a exemplo do levantamento realizado por Fonseca, Kumagai e Mielke (2006).
} 


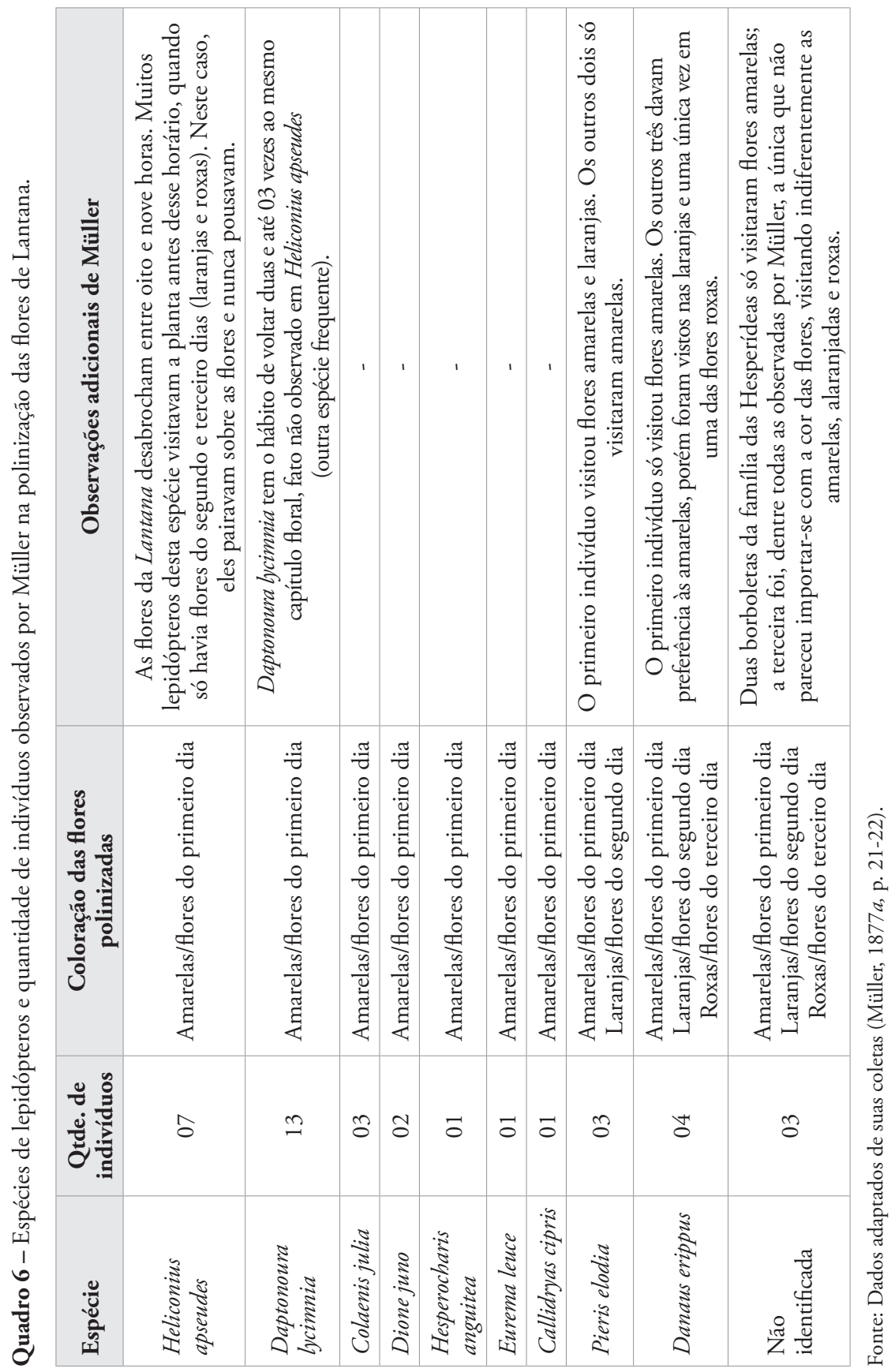


É interessante observar a apropriaçáo de Müller das ideias de Darwin em suas hipóteses: ele utiliza o conceito de instinto e hábito dos animais, discutido amplamente por Darwin em Origin (DARWIN, 1859, p. 207-244).

Para Darwin, os instintos são variações encontradas nos animais que podem ser herdadas e variadas por ação da seleção natural, que preserva e acumula continuamente as variaçóes do instinto na medida de sua utilidade para a espécie (DARWIN, 1859, p. 209). De acordo com ele, os hábitos são semelhantes aos instintos, visto que algumas das açóes hereditárias que poderiam ter surgido como hábito para alguma espécie, tornam-se, com o passar do tempo, tão indistinguíveis que se tornam parte do instinto.

Weiss (1991) repetiu os experimentos de Müller na Universidade da Califórnia (EUA) mais de um século depois dos testes realizados por este em Blumenau-SC. Como Müller, ela também observou que as flores de Lantana mudam, na mesma floração, a coloração de amarelo para laranja e, por fim, vermelho. Em determinado momento do experimento, seu estudo nota que as flores amarelas formavam entre 9 e 33\% de todas as flores do arbusto. Buscando analisar se as vermelhas (já polinizadas) ainda atraíam borboletas, a pesquisadora variou o número de flores e a quantidade de néctar para testar as preferências por determinada cor e notou que as borboletas sempre optam por capítulos com mais flores, independentemente da quantidade de néctar. Além disso, percebeu que havia borboletas que somente procuravam as flores amarelas de Lantana, enquanto outras visitavam as vermelhas e as amarelas, porém logo "aprendiam" a escolher as amarelas (no caso, as sexualmente viáveis).

As mudanças de coloração nas flores são comuns nas angiospermas, e em muitos casos estas mudanças são conhecidas por fornecerem sinais para polinizadores, o que, como Müller 
pressupóe no final de seu artigo, faz com que os insetos "aprendam por experiência” quais plantas devem visitar. Sobre este assunto há diversas pesquisas correlacionadas. Por exemplo, Weiss (1995) arrolou plantas de 77 famílias cujas flores mudam de cor devido à ação de antocianinas e carotenóides, relacionando a mudança com o tipo de polinizador que caracteristicamente visita a planta; Schaefer, Schaefer e Levey (2004) estudaram os sinais emitidos por flores e frutos, buscando compreender como os consumidores de frutas ou de néctar percebem esses sinais; Andersson e Dobson (2003) demonstraram que a seleção de flores por borboletas pode se dar tanto por características visuais (cores) quanto pelo aroma, sendo que em ambos os casos o comportamento forrageiro se mantém constante nas flores.

Pesquisas sobre mudanças de coloração em flores e sua relação com insetos específicos são tratadas atualmente em área específica da biologia, denominada ecologia da polinização, em que os atrativos florais dependem dos sentidos dos polinizadores, quer sejam químicos, visuais ou mecânicos.

\subsubsection{Os órgãos odoriferos dos lepidópteros}

Darwin tratou de forma breve em Origin o tema da seleção sexual; porém foi em The Descent of man que estabeleceu melhor o conceito, utilizado para resolver questóes levantadas à época, como a presença de caracteres diferenciados (nomeados de caracteres secundários) encontrados principalmente nos machos de diversas espécies. De maneira geral, seleção sexual se refere à "vantagem que certos indivíduos possuem sobre outros do mesmo sexo e espécie com respeito à reprodução" (DARWIN, 2002, p. 249), conforme exemplo a seguir:

Quando os dois sexos seguem exatamente os mesmos modos de vida e o macho tem os órgãos sensoriais e locomotores 
mais altamente desenvolvidos do que os da fêmea, poderia então acontecer que a perfeição destes fosse indispensável para o macho encontrar a fêmea; mas na grande maioria dos casos, eles servem somente para proporcionar a um macho vantagem sobre um outro visto que, depois de um certo tempo, os machos menos dotados conseguiriam acasalar-se com as fêmeas, e a julgar pela estrutura da fêmea, eles estariam sob outros aspectos igualmente bem adaptados aos seus modos de vida habituais. A seleção sexual deve ter aqui agido, pois em tais casos os machos adquiriram a sua estrutura presente não pelo fato de estarem em melhores condiçôes de sobreviver na batalha pela existência, mas pela circunstância de terem ganho uma vantagem sobre os outros machos e por terem transmitido esta vantagem somente em linhagem masculina. Foi a importância desta seleção que me levou a designar esta forma de seleçáo com o nome de seleção sexual (DARWIN, 2002, p. 249-250).

Para Darwin, a seleção sexual era evidente nos caracteres sexuais secundários, expressos em determinado sexo de uma espécie e ausentes no outro, distinguindo-se dos primários, representados pela diferença existente entre machos e fêmeas quanto aos órgãos de reprodução. Os caracteres sexuais secundários, que não tem conexão direta com a reprodução, podem ser órgãos sensoriais ou locomotores presentes em uma determinada espécie apenas em um sexo (no macho ou na fêmea), bem como o desenvolvimento de determinada estrutura em uma espécie, ausente em um sexo e presente no outro (DARWIN, 2002, p. 247).

Em consulta às correspondências disponíveis na literatura entre Darwin e Müller (ZILLIG, 1997) é possível notar que o tema seleção sexual já era debatido entre os dois naturalistas por cartas desde 1867. Em 17 de julho de 1867, Müller escreve a Darwin: 
Quanto à sua pergunta relativa à diversidade sexual entre os animais inferiores ${ }^{48}$, cabe talvez se referir aqui, a um de nossos Amphipodas, Brachyscelus diversicolor. F.M. O macho desta espécie $[\ldots]^{49}$, se diferencia não apenas através de suas antenas, cujo primeiro par é muito grosso e equipado com abundantes vibrissas, enquanto que o segundo é extraordinariamente longo (este segundo par falta nas fêmeas e nos jovens machos) senão também através de sua cor. A fêmea normalmente é de um branco leite ou de uma cor amarelo pálida, o macho é de um castanho vermelho escuro ou negro. A espécie tem olhos incomumentemente grandes, como de fato a maioria dos Hysperina ostem, e assim não é improvável que a fêmea seja atraída pela cor do macho (ZILLIG, 1997, p. 163).

Em 03 de junho de 1868, Darwin escreve a Müller agradecendo suas contribuiçóes acerca da observação do número desigual entre o sexo dos crustáceos, bem como "encomendando" ao naturalista uma pesquisa:

Muitos agradecimentos por todos os curiosos fatos acerca do número desigual de sexos nos crustáceos; mas quanto mais investigo este tema, mais profundamente caio em dúvidas e dificuldades" [...] Aqui há outro ponto; o senhor tem alguns tucanos? Se assim, pergunte a algum caçador confiável, se os bicos dos machos, ou de ambos os sexos, são coloridos mais brilhantemente, durante a estação de procriação do que nas outras épocas do ano (ZILLIG, 1997, p. 170).

Em consulta à correspondência entre ambos os naturalistas, não foi possível encontrar a carta remetida de Müller à qual Darwin agradece as contribuiçóes acerca dos crustáceos. Porém

\footnotetext{
48 Provavelmente houve uma carta anterior de Darwin para Müller, não disponível na literatura de consulta.

49 Suprimiu-se a classificação taxonômica da espécie, presente no original.
} 
em seu livro The descent of man, Darwin discute a proporção numérica entre os sexos de diversas espécies e provavelmente pediu a Müller nessa carta extraviada que o amigo observasse essa proporção entre os crustáceos catarinenses para acrescentar em suas discussóes. Provavelmente o conteúdo dessa carta extraviada sejam as observaçóes de crustáceos de Müller remetidas ao amigo, visto que seu nome e suas discussóes sobre o tema dialogam no original de Darwin (DARWIN, 1871, p. 307).

Em 22 de fevereiro de 1869, Darwin escreve a Müller comentando sobre a preparaçáo de seu material e novamente pedindo ao amigo notícias sobre o tema, provavelmente para incluir estas observaçóes em seu livro:

[...] Embora o senhor tenha me ajudado de maneira importante e extensa em tantas maneiras, estou para pedir alguma informação em dois outros tópicos. Estou preparando uma discussão sobre "seleção sexual", e quero muito saber quão baixo na escala animal se estende a seleção sexual de um tipo particular. O senhor sabe de algum animal inferior, no qual os sexos são separados, e nos quais o macho difere da fêmea em armas de ataque, como os chifres e presas dos animais mamíferos, ou numa plumagem pomposa e ornamentos, como nos pássaros e borboletas? (ZILLIG, 1997, p. 179).

E finalmente, em 28 de agosto de 1870, Darwin escreve acerca da publicação do livro: "Meu manuscrito foi enviado para a editora e suponho seja publicado dentro de 03 meses; naturalmente enviarei uma cópia ao senhor" (ZILLIG, 1997, p. 187).

Através da consulta às cartas entre os dois naturalistas, é possível perceber que Müller não só foi influenciado pelo conceito de seleção sexual de Darwin como o ajudou a construí-lo, principalmente em relação aos artrópodes e suas diferentes ordens, grupo que Müller possuía grande familiaridade (DARWIN, 1871, p. 247; 307; 319-327; 335; 341). 
O conceito de seleção sexual é utilizado por Müller para explicar a presença dos órgãos odoríferos em diversas regióes do corpo dos lepidópteros e também para explanar o dimorfismo sexual presente em diversas espécies. Em seus artigos acerca dos órgãos odoríferos nos Archivos ("As máculas sexuais dos indivíduos masculinos das espécies Danais erippus e D. gilippus"; "Os órgãos odoríferos das espécies Epicalia acontius, Lin. e de Myscelia orsis, Dru."; "Os órgãos odoríferos nas pernas de certos Lepidopteres"; "Os órgãos odoríferos nas pernas de certos Lepidopteres (Suplemento)" e "Os órgãos odoríferos da Antirrhaea archaea Hübner"), ele busca estabelecer a relação destes com uma possível função sexual para as espécies que o apresentam. $\mathrm{Na}$ época, muitos pesquisadores descreviam tais órgãos, porém não os correlacionavam a funções específicas; trabalho realizado por Müller e posteriormente lembrado na literatura específica acerca destes estudos (COSTA-LIMA, 1950; BARTH, 1960).

Barth (1913-1978) se dedicou à descrição minuciosa dos órgãos odoríferos dos lepidópteros, e seu livro é utilizado até os dias atuais por especialistas do assunto. Segundo este autor, os lepidópteros podem ter dois tipos de órgãos odoríferos: os simples (endócrinos) e os compostos (exócrinos). Os órgãos simples são aqueles nos quais as secreçóes das células glandulares atravessam diretamente a cutícula da área glandular para depois evaporar sobre esta; já os órgãos compostos são aqueles em que as escamas odoríferas transmitem as secreçóes para as escamas, cerdas ou pelos de formação especial, dispostos em forma de tufo, feltro ou pincel, que se enchem de secreçóes (BARTH, 1960, p. 11). Ainda de acordo com Barth, a localização dos órgãos odoríferos varia de espécie para espécie, podendo aparecer em áreas glandulares nas asas, na cabeça, na base das antenas, pernas ou no abdômen (BARTH, 1960, p. 11-15). 
O primeiro trabalho de Müller sobre os órgãos odoríferos aparece no volume de 1877, sob o título de: As máculas sexuais dos indivíduos masculinos das espécies Danaus erippus ${ }^{50} \mathrm{e}$ Danaus gilippus (MÜLLER, 1877b).

O termo mácula sexual (sexual spot) foi cunhado pelos entomologistas Doubleday e Westwood, que publicaram na segunda metade do século XIX, em dois volumes, o livro Genera of diurnal lepidoptera (1846-1852), intensamente consultado pelos pesquisadores da época. Nos dias atuais, a estrutura é denominada como mancha androconial, presente nas asas de certas espécies de lepidópteros.

Müller expóe ao seu leitor, referências encontradas na literatura acerca das máculas sexuais presentes nas asas de borboletas do gênero Danaus, categorizando-as em quatro grupos distintos (segundo a posição das chamadas máculas nas asas) conforme os entomólogos Doubleday e Westwood (1856-1860:89-90) o fizeram em Genera of diurnal lepidoptera. Apesar de Müller não citar em seu trabalho qual foi o volume utilizado da obra que consultou, nesta pesquisa observou-se que ele utilizou as páginas 89 a 91 do primeiro volume, que tratam do gênero de borboletas supracitado.

Como Müller informa, seu interesse pelo estudo das chamadas máculas sexuais deve-se a "descobertas recentes" de que estas na verdade são órgãos odoríferos que "exalam um cheiro às vezes bastante forte, certamente agradável às fêmeas das respectivas espécies" (MÜLLER, 1877b, p. 26).

Tais "descobertas recentes" são as suas próprias pesquisas, publicadas no mesmo ano na revista Kosmos e distribuídas em quatro artigos, sob o título: Beobachtungen an brasilianischen

50 Danaus erippus Cramer é popularmente conhecida como Borboleta monarca do Sul. Na literatura, a espécie é tratada como uma subespécie da norte-americana, Danaus plexippus L.; porém estudo de cruzamentos entre ambas revelou tratar-se de espécies diferentes (HAY-ROE, LAMAS, NATION, 2007). 
Schmetterlingen (Observaçóes em borboletas brasileiras). No primeiro deles, Müller pressupóe que as chamadas máculas sexuais das asas, características dos machos de algumas espécies de borboletas são, na verdade, órgãos odoríferos que exalam odor característico para atração de fêmeas respectivas.

No trabalho dos Archivos ele descreve a localização e a possível função das máculas nas duas espécies do gênero Danaus, atendendo ao princípio de seleção sexual: para ele, as máculas dos machos de ambas as espécies possuem como função a liberaçâo de odor, utilizado como atrativo sexual de cópula para as fêmeas respectivas.

Além de descrever as máculas das asas, relata também outra estrutura conhecida como pincel de pelos, para a qual também atribui uma função odorífera de atração de fêmeas. Tal órgão peculiar, descrito morfologicamente por ele, e também narrado na literatura contemporânea específica, tal qual as investigaçóes de Müller propuseram, possui funçáo sexual, visto que libera feromônios ejetados na fêmea durante a cópula. De fato, as borboletas machos da subfamília Nymphalidae Danainae, na qual se incluem as espécies estudadas pelo naturalista, possuem pelos abdominais liberadores de feromônios como atrativos femininos (EDGAR, CULVENOR, PLISKE, 1974). Outro estudo demonstra, inclusive, que a fêmea de Danaus gilippus Cramer não acasala até que o macho tenha escovado seus pelos abdominais perfumados sobre sua cabeça e antenas (PLISKE, SALPETER, 1971), pois, após a escovação é que se libera o feromônio necessário para o acasalamento sexual.

No final desse artigo, Müller relata um fato que, em suas próprias palavras, "convém não deixar despercebida circunstância alguma, por mais insignificante que possa parecer" (MÜLLER, $1877 b$, p. 28). Tal episódio descrito vem da observação de que determinado macho possuía na asa, perto da cavidade da mácula, uma pequena parte descamada, como se algum objeto 
tivesse sido introduzido na cavidade. $\mathrm{O}$ autor pressupóe que os pelos odoríferos abdominais de alguma forma se introduziriam nessa cavidade, que por sua vez seria a responsável pela produção da substância odorífera que impregnava nos pelos. Devido à localização dos pelos odoríferos, e pelo fato de estes saírem do abdômen unidos tal qual um pincel, Müller acredita que tal façanha não seja impossível e nem difícil, só restando outros estudos complementares e comparativos para a resolução dessa questão; o que, foi realizado por Illig em 1902 e Freling em 1909, (apud Barth, 1960, p. 128-129) ${ }^{51}$. Estes autores descreveram o tubo abdominal em borboletas do gênero Danaus, bem como sua função odorífera abastecedora do pincel, tal qual as investigaçóes de Müller propuseram.

Quanto às máculas sexuais (ou androconiais), estudos posteriores revelaram que Müller está correto: são glândulas exócrinas com feromônio sexual masculino para atração de fêmeas (DEVRIES, 1987). Tais órgãos emitem sinais químicos funcionando como uma espécie de sinalizador para a fêmea escolher um macho de qualidade (seleção interespecífica) e também para o reconhecimento da espécie (BOPPRÉ 1984, SCHULZ et al. 1993, apud BORGES, 2012).

Outro artigo publicado no mesmo ano (MÜLLER, 1877c) por Müller descreve os órgãos odoríferos das espécies Epicalia acontius $^{52}$ L. e de Myscelia orsis Dru., que apresentam dimorfismo sexual muito evidente, conforme demonstrado nas Figuras 11 (a, b, c, d) e 12 (a, b, c, d).

\footnotetext{
51 Barth (1960, p. 128-129) cita as descriçóes que Müller realizara para ambas espécies do gênero Danaus referentes ao tubo abdominal e às manchas odoríferas. 52 Espécie designada atualmente de Catonephele acontius L. Na época em que Müller escreveu seu artigo, ele apresentou duas sinonímias para o gênero: Epicalia, de acordo com a classificaçáo de Westwood (1850), e Catonephele, de acordo com a classificação de Hübner (1819).
} 


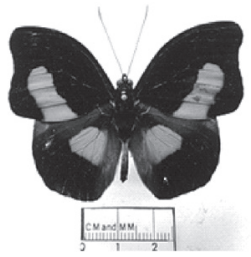

Figura 11a: Macho de Catonephele acontius, vista dorsal.

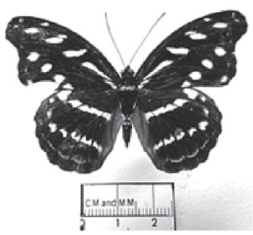

Figura 11c: Fêmea de Catonephele acontius, vista dorsal.

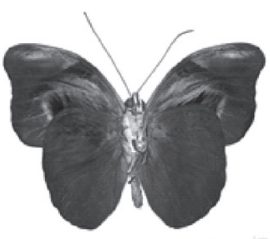

Figura 11b: Macho de Catonephele acontius, vista ventral.

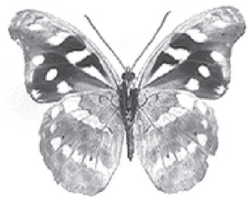

Figura 11d: Fêmea de Catonephele acontius, vista ventral.

Fonte: Lepidoptera Braziliensis (Site) (2001).

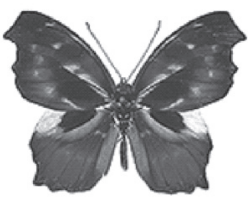

Figura 12a: Macho de Myscelia orsis, vista dorsal.

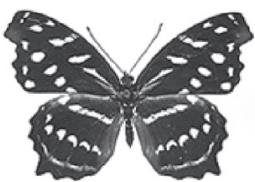

Figura $12 c$ : Fêmea de Myscelia orsis, vista dorsal.

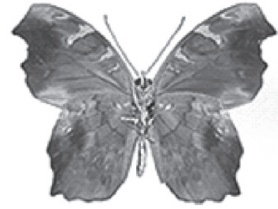

Figura 12b: Macho de Myscelia orsis, vista ventral.

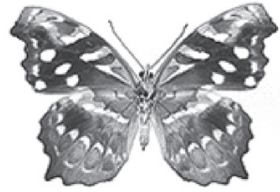

Figura 12d: Fêmea de Myscelia orsis, vista ventral.

Fonte: Lepidoptera Braziliensis (Site) (2001). 
Este dimorfismo é tratado por Müller nas linhas iniciais do artigo, para as duas espécies do gênero Epicalia:

O gênero Epicalia West. (ou Catonephele Hubn) tem adquirido certa fama pela diferença extraordinária que exibem no colorido das asas os dois sexos de várias espécies suas representantes. Se v.g. ${ }^{53}$ compararmos a Epicalia numilia Cram. com a Epicalia acontius Lin., veremos que as fêmeas das duas espécies, e da mesma sorte os machos, são muito mais semelhantes entre si do que cada uma das fêmeas ao seu próprio macho (MÜLLER, 1877c, p. 31).

Essa "fama”, da qual trata o excerto, é atribuída por Müller às descriçóes realizadas por Darwin para o gênero em seu livro, The Descent of man, que propóe o conceito de seleção sexual.

Darwin utilizou em seu livro os estudos de Henry Walter Bates (1825-1892) sobre a coloração de espécies do gênero Epicalia para explicar o dimorfismo sexual existente nos lepidópteros. Para Darwin, os estudos de Bates com Epicalia serviam como modelo para a suposiçáo de que todas as espécies do gênero descendiam de uma forma originária comum que possuiria um colorido quase da mesma maneira (DARWIN, 2002, p. 367). A fim de explicar o porquê da diferença de cores entre os sexos de uma mesma espécie de borboletas, ele levanta duas hipóteses: ou a variaçáo de cores serviria como proteçáo a predadores ou para a atraçáo do sexo oposto. A hipótese de proteção contra predadores é examinada e logo descartada, uma vez que o ventre destas borboletas possui cores neutras, o que já lhes permitiria fugir do perigo natural (DARWIN, 2002, p. 369). Resta a hipótese de que a variaçáo das cores dentro da espécie poderia servir como atraçáo do sexo oposto, na qual se inclina

53 A abreviação utilizada por Müller vem do latim: verbi gratia e significa por exemplo. 
a pressupor que "fêmeas preferem ou se sentem mais excitadas pelos machos mais vistosos; porque, se supomos o contrário, pelo que nos é dado a investigar, os machos desta maneira teriam adornos sem nenhuma finalidade" (DARWIN, 2002, p. 371).

$\mathrm{O}$ conceito de seleção sexual aplicado às borboletas por Darwin buscava explicar as diferenças dos padróes de coloração de machos e fêmeas de uma mesma espécie. Acresce a isso que Darwin considerava que os machos que apresentavam cores mais vivas deveriam ter sido escolhidos para acasalamento durante muitas geraçóes, fazendo com que esta característica fosse transmitida aos dois sexos, ou a um somente, de acordo com a lei da hereditariedade.

Nos dias atuais é aceita a ideia de que a evolução dos caracteres sexuais secundários se deve, principalmente, às diferenças no investimento parental (ANDERSSON, 1994). Nesse sentido, se machos e fêmeas investem de forma equivalente no cuidado parental, não há desenvolvimento de caracteres sexuais secundários, ao passo que se o investimento dos machos é maior do que o das fêmeas, estas adquirem características dimórficas; e quando fêmeas investem mais no cuidado parental do que os machos, estes é que competem e evoluem tais características.

Em relação aos órgãos odoríferos, Müller observou que os machos de Epicalia numilia Hübner (atual Catonephele numilia Hübner) não possuem nenhum vestígio destes; ao mesmo tempo que os machos de Epicalia acontius os possuem, os quais exalam odor muito forte e se localizam entre as asas anteriores e posteriores (MÜLLER, 1877c, p. 32). Ele realiza uma descrição minuciosa das máculas odoríferas presentes nas asas dessa espécie, fornecendo medidas em milímetros, bem como a localização das estruturas entre as nervuras das asas. 
Quanto à outra espécie, Myscelia orsis, os estudos de Herrich Schaffer mostram que a espécie possui uma mancha na superfície superior das asas posteriores dotada de pelos; porém o pesquisador não apresenta as dimensôes dessas manchas em seu trabalho - Müller, por sua vez, realiza a tarefa e contribui ao tema.

Ao fim do artigo, nota-se a preocupação de Müller, em consonância a outros evolucionistas da época, em estabelecer posiçóes intermediárias entre os gêneros, com base na ideia de seleção natural e de um ancestral comum:

Deste modo, no tocante às máculas felpudas, o macho de Myscelia orsis ocupa uma posição intermédia entre a Epicalia numilia, que carece de semelhantes máculas, e a Epicalia acontius, que as possui também nas asas anteriores. À vista deste fato, é permitido duvidar sobre si os limites entre os dois gêneros já se acham devida e definitivamente estabelecidos (MÜLLER: 1877 c, p. 34).

Bizzo (2007) faz uma interessante analogia acerca da questáo de procura de documentação fóssil para estabelecer tipos intermediários para as espécies viventes. De acordo com este autor,

As intervençōes divinas, ajustando os seres vivos ao meio ambiente, dispensavam qualquer linha de continuidade entre os seres vivos. $\mathrm{O}$ criador poderia simplesmente inovar em dado momento, assim como um cozinheiro pode mudar o tipo de refeição que prepara todos os dias (BIZZO, 2007, p. 358).

Porém, a partir do momento em que as teorias de Darwin começaram a ser utilizadas para explicar o mundo natural, "o cardápio evolutivo" permitiu a realizaçáo de previsôes, como se "a almôndega de hoje corresponderia à carne moída de ontem e ao bife de anteontem" (BIZZO, 2007, p. 358). 
Os naturalistas que utilizavam a teoria da seleção natural para explicação dos fenômenos buscavam reafirmá-la, estabelecendo árvores genealógicas, bem como procurando espécies que pudessem ser consideradas intermediárias para alguma característica distintiva estudada. O próprio diretor da seção de Antropologia, Zoologia Geral e Aplicada e Paleontologia do $\mathrm{Mu}$ seu Nacional, Dr. João Joaquim Pizarro (1842-1906) em 1876, afoito em contribuir com um estudo inédito acerca da questão, publica no primeiro volume dos Archivos o seguinte artigo: Nota descritiva de um pequeno animal extremamente curioso e denominado Batrachychthis. Na publicação, Pizarro (1876) acredita ter encontrado uma forma transitória entre dois grupos de vertebrados (anfíbios e répteis); porém, em sua descrição textual e iconográfica, é possível notar que ele se refere à metamorfose de uma râ, desenvolvimento metamórfico diferente dos outros anuros, e que ele desconhecia. $\mathrm{O}$ artigo o tornou um célebre às avessas entre os estrangeiros, motivo de piada, conforme levantou Gualtieri (2008, p. 55-59) em suas pesquisas.

Apesar de Müller também buscar correlacionar formas intermediárias a fim de demonstrar como certas características dos organismos foram produzidas sob a influência da seleção natural, observa-se uma certa cautela do autor em não concluir demasiadamente rápido suas especulaçóes; diferentemente de Pizarro, severamente criticado por ter atraído o "ridículo ao Museu Nacional" na época (MIRANDA-RIBEIRO, 1945 apud GUALTIERI, 2008, p. 58).

Ainda no volume de 1877, Müller descreve os órgãos odoríferos localizados nas pernas de certos lepidópteros (Os orgãos odoriferos nas pernas de certos Lepidopteres).

Mais uma vez, inicia seu artigo (MÜLLER, 1877d, p. 39) esclarecendo que as diferenças sexuais dos lepidópteros, inexplicáveis anos antes, já estavam se tornando claras e inteligíveis 
devido a estudos contemporâneos que buscavam elucidar a razáo de existirem determinadas características e distinçôes morfológicas, principalmente entre machos e fêmeas da mesma espécie.

Müller cita seu próprio trabalho, incluído no volume IX da Jenaische Zeitschrift für naturwissenschaft (1877). No artigo Ueber Haarpinsel, Filzflecke und ähnliche Gebilde auf den Flügeln männlicher Schmetterlinge (Sobre pincéis de pelos, manchas de escamas e estruturas similares nas asas de borboletas macho), estabelece a função dos órgáos odoríferos. Há também nesse volume da revista outro artigo sobre o tema, de autoria de Berthold Hatschek (1854-1941), cujo título é Beiträge zur Entwicklungsgeschichte der Lepidopteren (Contribuiçôes para a história do desenvolvimento dos lepidópteros), outro "estudo contemporâneo" sobre o tema em questão.

Novamente há uma preocupação do autor em atribuir ao seu trabalho o ineditismo das pesquisas sobre função dos órgãos odoríferos, conforme reforça no excerto: "Quanto, enfim, aos pincéis e aparelhos análogos, que existem nas pernas de certos lepidópteros, e só no sexo masculino, ninguém até hoje, que eu saiba, falou na função que eles possam exercer" (MÜLLER, 1877d, p. 39).

Utilizando a obra Genera of Diurnal Lepidoptera, de Doubleday e Westwood, Müller descreve os pincéis de pelos nas pernas de certas espécies de borboletas, atribuindo às estruturas uma função sexual, visto que estas também exalam odor (cada espécie possui um odor diferente) para atração das respectivas fêmeas (MÜLLER, 1877d, p. 39-41).

$\mathrm{Na}$ pesquisa, o autor encontrou variedades em relaçáo à posição morfológica desses órgãos odoríferos dentro de uma mesma família de borboletas ${ }^{54}$, e pressupôs que essas diferenças

\footnotetext{
54 Certos machos possuem órgãos odoríferos nas tíbias posteriores; outros nas tíbias anteriores; outros no fêmur das pernas médias; e outros não possuem nenhum tipo de órgão odorífero associado às pernas (MÜLLER, 1878a).
} 
não foram herdadas de um progenitor comum da família, mas sim adquiridas posteriormente pelas várias espécies que possuíam estes atrativos (MÜLLER,1877d, p. 45).

Esta pressuposição dialoga novamente com os argumentos de Darwin quanto às leis da variação: caracteres específicos de uma espécie sofrem mais variaçôes do que os genéricos, afastando-se, por conseguinte, do ancestral comum; da mesma forma que os caracteres sexuais secundários sofrem grande variabilidade entre espécies muito próximas. Esta variabilidade é explicada pela ação conjunta da seleção natural e da seleção sexual (DARWIN, 1859, p. 131-170).

Os pincéis de pelos já estudados por Müller aparecem na literatura contemporânea como produtores de feromônios (cetonas, lactonas, etc.), cujo papel comportamental é a atração sexual de fêmeas (TUMLINSON, et al., 1982). Hillier e Vickers (2004) estudaram o comportamento de um feromônio na espécie Heliothis virescens Fabr. No trabalho, os autores submeteram as fêmeas a diferentes extratos de feromônios masculinos, e observaram que o macho liberador de maior quantidade de feromônio era o escolhido por elas, desempenhando um papel seletivo na escolha do parceiro.

No terceiro volume de Archivos (1878), Müller publicou seus dois últimos artigos no periódico sobre os órgãos odoríferos. $\mathrm{O}$ artigo Os órgãos odoriferos da Antirrhaea archaea Hübner, abre a edição do volume III.

Com o auxílio de microscópio, observou que, após a escamação das asas, as máculas sexuais não possuíam um padrão, variando de indivíduo para indivíduo dentro do mesmo sexo. Assim como Darwin, Müller supóe que as mudanças de condiçóes de vida poderiam causar essas variaçóes sobre todo o organismo ou sobre algumas partes do organismo e atribui essa variabilidade 
encontrada ao conceito de Darwin, de que "a parte desenvolvida em alguma espécie, num grau ou maneira extraordinária, em comparação com a mesma parte em espécies aliadas, tende a tornar-se consideravelmente variável" (MÜLLER 1878a, p. 5).

Outro ponto de sua descrição, mais uma vez em diálogo com Darwin, é o seguinte:

[...] a separação em duas partes do órgão odorífero, parecendo ser reservada às asas posteriores a produção, e às anteriores a emissão ou exalação do cheiro que deve seduzir as fêmeas amorosas. Quanto à mácula opaca das asas anteriores, parece ser um órgão odorífero rudimentário, ficando por ora indeciso, se acha em via de progresso ou de regresso, se mais tarde deve aperfeiçoar-se ou desaparecer (MÜLLER:1878a, p. 5).

Nota-se neste excerto grande influência das ideias referentes à lei do uso e do desuso, a qual Darwin também utilizava em combinação com a seleção natural. Apesar de atualmente tal teoria não ser aceita, visto que as modificaçôes na parte somática do corpo não são herdadas, Darwin explicava muitas estruturas dos animais por esta lei, em que o uso reforça e desenvolve alguma estrutura enquanto o desuso a atrofia, conforme o excerto:

Eu penso haver poucas dúvidas de que nos nossos animais domésticos, o uso fortalece e amplia certas partes, enquanto o desuso tende a diminuí-las; e que tais modificaçóes são herdadas. Em animais de natureza livre, não temos nenhum padrão de comparação para julgar os efeitos do uso e desuso a longo prazo, visto que náo conhecemos os progenitores; mas muitos destes animais possuem estruturas que podem ser explicadas pelos efeitos do desuso (DARWIN, 1858, p. 135).

Outra questáo levantada por Müller em diálogo com Darwin refere-se à homologia e analogia de órgãos. $\mathrm{Na}$ época, 
a homologia era explicada com base nos órgãos que possuíam um padrão semelhante em organismos diferentes, sustentando a teoria da descendência comum; enquanto a analogia referia-se à semelhança morfológica de estruturas, em função de adaptação à execução de uma mesma atividade.

Müller comparou os órgãos odoríferos da Antirrhaea arhaea Hübner com os de Epicalia acontius. Em ambos, encontrou a superfície inferior das asas anteriores munida de um pincel de pelos inseridos ao longo da nervura interna, que cobria uma mácula bem desenvolvida em Epicalia acontius e rudimentar em Antirrhaea arhaea. Esta semelhança das estruturas, de acordo com ele, poderia ser explicada se ambas pertencessem ao mesmo gênero por terem um progenitor comum. Porém, como nos esclarece, são espécies de subfamílias distintas ${ }^{55}$, levando-o a considerar que tais órgãos não são estruturas homólogas e sim análogas, constituindo um exemplo dos "mais notáveis de convergência como modernamente se tem chamado a semelhança que não resulta de herança, e sim provém da adaptação a circunstâncias idênticas" (MÜLLER: 1878a, p. 5-06).

Tal convergência, à qual se refere, provém das primeiras ideias surgidas no final do século XIX, acerca do desenvolvimento de características semelhantes em organismos diferentes, decorrentes da adaptação a uma condição ecológica igual, demonstrando o quanto Müller possuía conhecimento acerca das discussóes atuais concernentes ao tema. Por fim, seu último artigo, A prega costal das Hesperiideas ${ }^{56}$, busca demonstrar que a prega costal (atual dobra costal), também é um órgão odorífero (MÜLLER, 18786).

\footnotetext{
${ }^{55}$ Epicalia inclui-se na subfamília das Nymphalideas, enquanto Antirrhaea nas Satyrideas.

${ }^{56}$ As Hesperiidae (ordem Lepidoptera, superfamília Hesperioidea) dividem-se em 3 subfamílias: Pyrrhopyginae, Pyrginae e Hesperiinae, todas com representantes sul-americanos (CARNEIRO; MIELKE; CASAGRANDE, 2013).
} 
Como no início do século XXI, diversos estudos também descrevem órgãos odoríferos nos lepidópteros. Exemplos para diferentes espécies e em diferentes partes do corpo são escamas odoríferas (DIAS; CASAGRANDE; MIELKE, 2012), tanto em formato de pincéis de pelos abdominais (HILLIER, VICKERS, 2004) como nas dobras costais (CARNEIRO; MIELKE; CASAGRANDE, 2013), sendo que sua função geralmente está correlacionada à liberação de feromônios para atração das fêmeas.

Muitos dos conceitos utilizados por Müller mudaram de significação biológica ou não são mais utilizados no decorrer dos mais de cem anos da publicação original. A lei do uso e do desuso e da herança dos caracteres adquiridos, por exemplo, são conceitos não mais empregados. Porém, é importante ter em mente que as ideias referentes à herança dos caracteres adquiridos, erroneamente atribuídas a Lamarck pelos livros didáticos, já eram defendidas desde a Antiguidade por Aristóteles. No século XVIII, diversos tratados médicos também mencionam a herança dos caracteres adquiridos e Darwin também a aceitava em combinação com a seleção natural.

No final do século XIX, os próprios conceitos de seleção natural, gradualismo e especiação foram rejeitados, sendo posteriormente reaceitos durante a síntese evolucionista da década de 1940, a qual Mayr (2009, p. 341) denomina como segunda revolução darwiniana. Parte desta reaceitação se deve à nova "roupagem" dos conceitos dada pelos trabalhos de herança de Mendel (1822-1884). Assim, conteúdos como os da própria seleção natural, somados a estudos genéticos e posteriormente moleculares, tornaram o que atualmente se conhece como teoria sintética da evolução.

Roquette-Pinto, em discurso de 1929, quando da ocasião de inauguração da estátua em homenagem a Müller na cidade de 
Blumenau-SC, ilustra bem esse período de rejeição ao evolucionismo, conforme o excerto:

Atualmente, a influência da "luta pela existência" na formação de novas espécies não tem mais o prestígio antigo... De sorte que todas as velhas explicaçóes do mimetismo, propostas nos "tempos heroicos" do transformismo, perderam quase o seu valor. $\mathrm{O}$ espírito finalista, que sempre foi a grande sombra do evolucionismo, acabou prejudicando o sistema (ROQUETTE-PINTO, 2000, p. 41).

Esta rejeição às teorias de Darwin no final do século XIX e início do XX se deve, em parte, aos estudos de August Weismann (1834-1914) em meados de 1880 que, através de experimentos e observaçôes microscópicas, concluíram que alteraçôes nos tecidos somáticos não eram transferidas aos descendentes; excluindo dessa forma da teoria de Darwin os pressupostos já defendidos por Lamarck em relação à herança dos caracteres adquiridos, iniciando uma explosão de teorias antidarwinistas como o neodarwinismo ${ }^{57}$, neolamarckismo ${ }^{58}$, ortogênese $\mathrm{e}^{59} \mathrm{e}$ mutaçăo ${ }^{60}$, muito difundidas no Brasil no período supracitado.

57 O neodarwinismo, de maneira geral, refere-se ao movimento que buscou separar os fatores evolutivos não darwinianos do darwinismo biológico (GUALTIERI, 2008, p. 210). Nesse sentido, dentro do próprio grupo havia aqueles que consideravam as ideias lamarckistas complementares às de Darwin, outros que não aceitavam a seleção natural e ainda aqueles que rejeitavam o processo evolutivo como gradual.

58 O neolarmarckismo possuía duas vertentes: aqueles que aceitavam a herança dos caracteres adquiridos como mecanismo intencional no processo evolutivo e aqueles que acreditavam na tendência inerente que forçava os organismos a ascenderem nas escalas da vida (GUALTIERI, 2008, p. 210).

59 A ortogênese se refere a uma evolução linear dos seres vivos em uma única direção (GUALTIERI, 2008, p. 211).

${ }^{60}$ Nessa teoria, as mutaçôes ocorriam no plasma germinativo decorrentes de uma força inerente ao organismo (GUALTIERI, 2008, p. 211). 


\subsection{Estudos sobre tricópteros}

Sobre os tricópteros (Quadro 7), Müller publicou oito artigos científicos (SCHLENZ, FONTES, HAGEN, 2012, p. 48-61) referentes à descrição morfológica dos adultos, larvas e ovos, bem como das casas construídas pelas larvas (Figura 13). Fröhlich (1966, p. 384) ressalta que a obra de Müller acerca dos insetos aquáticos (nos quais também se incluem os dípteros), possuem observaçóes excelentes e desenhos cuidadosos. Porém, a parte sistemática é tratada de maneira bastante sumária, devido à deficiência de equipamentos. Esse mesmo autor aponta que há 23 referências acerca dos tricópteros nas correspondências de Müller, endereçadas a outros naturalistas, como Ernst Haeckel, e seus irmãos Herman e Wilhelm.

Quadro 7 - Principais características da ordem Trichoptera

\begin{tabular}{|c|c|c|}
\hline $\begin{array}{c}\text { Etimologia: trichos } \\
\text { significa pelos e pteron, } \\
\text { asa. As referências }\end{array}$ & $\begin{array}{c}\text { Sáo insetos holometábolos } \\
\text { com larvas aquáticas. As }\end{array}$ & $\begin{array}{c}\text { Dentre as ordens } \\
\text { de insetos } \\
\text { larvas constroem casas }\end{array}$ \\
$\begin{array}{c}\text { exclusivamente } \\
\text { nas asas. }\end{array}$ & ou abrigos com seda & aquáticos, é a mais \\
das glândulas salivares & diversa. A aparência \\
Desenvolvem-se na & modificadas e utilizando & dos adultos é variada, \\
maioria dos ambientes & diversos tipos de materiais, & lembrando pequenas \\
permanentes de & como folhas, areia, & mariposas. \\
água doce. & fragmentos de rocha etc. & \\
\hline
\end{tabular}

Fonte: Rafael et al. (2012, p. 614-615).

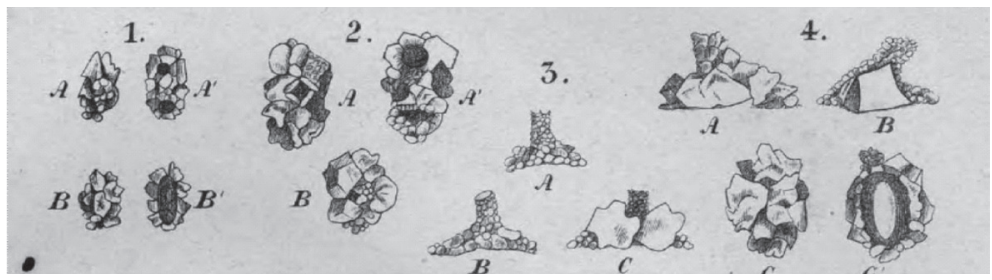

Figura 13 - Exemplo de casas construídas por diferentes famílias de tricópteros, desenhos realizados por Müller.

Fonte: Müller (1878c: VIII). 
No Archivos, Müller publicou somente um artigo sobre a ordem, dividido em duas partes (introdução e suplemento): Sobre as casas construidas pelas larvas de insectos trichopteros da provincia de Santa Catharina. Neste, descreve minuciosamente as casas das diversas famílias encontradas, estabelece novos gêneros e espécies, bem como fornece 39 figuras, a maioria destas posteriormente reproduzidas na obra de Costa Lima, Insetos do Brasil (1943). Este mesmo autor atribuiu:

A esse sábio alemão devemos uma das mais valiosas contribuiçôes à biologia dos tricópteros, publicada em nossa língua, nos "Archivos do Museu Nacional" do Rio de Janeiro (1881) [sic], após pacientes observações por ele feitas em Santa Catarina (COSTA-LIMA, 1943, p. 121) ${ }^{61}$.

Calor (2008, p. 176) em sua revisão taxonômica dos dois gêneros de tricópteros (Grumichella Müller e filogenia de Grumichellini Morse) também comentou acerca das descriçôes de Müller para o gênero, bem como atribuiu a ele o início dos trabalhos sobre a ordem no Brasil.

Müller descreveu as construçóes ou "casinhas" (como denomina) dos tricópteros; assunto que, de acordo com suas observaçóes, já havia sido publicado na Europa, mas que carecia de conhecimento acerca das espécies da América, em particular do Brasil (MÜLLER:1878c, p. 100). Os autores citados e utilizados por ele que já trabalharam com a ordem são os seguintes: Pictet, Kolenati, Hagen e MacLachlan. Todos pesquisaram e descreveram espécies europeias; por essa razão era imprescindível, de seu

\footnotetext{
${ }^{61} \mathrm{O}$ autor se equivoca ao apresentar o ano em que Müller publica sobre a ordem nos Archivos. O correto é 1878.
} 
ponto de vista, estudos no Brasil ${ }^{62}$ que contribuíssem ao aspecto filogenético e biológico da ordem (MÜLLER:1878c, p. 100).

No aspecto filogenético, Müller pressupóe que tanto tricópteros quanto lepidópteros teriam surgido a partir de um ancestral comum que teria dado origem a ambas as ordens, corroborando as premissas do evolucionismo darwinista. Apesar de o registro fóssil conhecido apresentar-se insuficiente para este possível elo evolutivo, sabe-se que a ordem mais próxima dos lepidópteros é a dos tricópteros (BORROR; DELONG, 1969), que provavelmente teriam evoluído a partir de um ancestral comum, conforme pressuposição de Müller.

Já no aspecto biológico, Müller considera a construção dessas "casas" ou estojos um aspecto interessante a ser discutido, visto que diferem na arquitetura; e esta diferença sugere tratar-se de gêneros distintos, conforme Bremi-Wolf ${ }^{63}$ já relatara, e ele também busca contribuir com a descrição e proposição de novos gêneros catarinenses (MÜLLER:1878c, p. 100).

Um ponto interessante a ser comentado é que Müller possuía uma extrema curiosidade sobre a organização de "casas" de insetos, e sobre aspectos biológicos, filogenéticos e sociais das diferentes ordens. Exemplo disso são seus trabalhos sobre as abelhas sem ferrão, em que explorou aspectos biológicos e sociais de diversas espécies, bem como acompanhou diariamente a

\footnotetext{
62 Hagen publicou em 1864 uma lista descritiva de 150 espécies de tricópteros, sendo que apenas dois destes eram de insetos do Brasil. Essa descrição de Hagen só foi possível a partir das observaçóes anteriores do naturalista Saint-Hillaire (17791853) que publicou diversas obras na Europa acerca de suas viagens ao Brasil (MÜLLER, 1878c).

${ }^{63}$ Johann Jacob Bremi-Wolf (1791-1857) propôs o gênero Helicopsyche em 1848 a partir da observação das casas das larvas e percebendo as diferenças existentes na arquitetura destas para outros gêneros dentro da mesma família (Phryganideas) (MÜLLER, 1878c).
} 
construção das células, chegando a desabafar em carta ao irmão Hermann que passou cerca de seis semanas levantando de uma a duas vezes por noite para observar a construção (NETTO, 1966, p. 378-381). Outro tema que também o interessava eram as diversas espécies de cupins de Santa Catarina, chegando a publicar, em 1873, quatro artigos sobre este tema no periódico alemão Jenaische Zeitschrift für Medizin und Naturwissenschaft . De acordo com a análise destes artigos realizada por Fontes (2007), muitas das informações são inéditas para a termitologia e utilizadas amplamente sem dar crédito ao autor:

Em realidade, nem se credita a informação original a Fritz Müller, ou porque a história da descoberta perdeu-se no tempo e esse conhecimento pioneiro é usado como se fosse de domínio público, desobrigando-se o usuário de citar o autor da descoberta, ou porque os artigos originais estão publicados em alemão, em periódico científico da década de 1870 (disponível em pouquíssimas bibliotecas) (FONTES, 2007, p. 31).

Quanto aos tricópteros, só foi possível encontrar referências aos estudos de Müller na obra de Costa Lima (1943) e na de Calor (2008), excluindo-se as publicações que apresentam a taxonomia de gêneros e espécies e que geralmente atribuem os créditos ao nomeador.

Foi possível encontrar atribuição a Müller para nove gêneros catarinenses, a saber: Dicaminus Müller, 1879; Peltopsyche Müller, 1879; Rhyacopsyche Müller, 1879; Nectopsyche Müller, 1879; Grumicha Müller, 1879; Phylloicus Müller, 1880; Marilia Müller, 1880; Itanara Müller, 1888; Eutonella Müller, 1921 equinze espécies: Dicaminus ladislavii Müller, 1879; Oxyethira hyalina Müller, 1879; Oxyethira spirogyrae Müller, 1879; Peltopsyche maclachlani Müller, 1879; Peltopsyche sieboldii Müller, 1879; Rhyacopsyche hagenii 
Müller, 1879; Phylloicus bromeliarum Müller, 1880; Phylloicus major Müller, 1880; Phylloicus medius Müller, 1880; Nectopsyche gemma, Müller, 1880; Marilia major Müller, 1880; Marilia minor Müller, 1880 Leptonema engnathum Müller, 1921; Eutonella peltopsychodes Müller, 1921; Nectopsyche modesta Müller, 1921; demonstrando o quanto suas pesquisas foram importantes para a área.

A primeira parte do artigo, Sobre as casas construidas pelas larvas de insectos trichopteros da provincia de Santa Catharina, é subdividida em seis partes. $\mathrm{O}$ suplemento também é subdividido baseado nessa primeira classificaçấo e nele o autor se propóe "não só completar a lista das espécies catarinenses, como também precisar a sua posição sistemática melhor do que me foi possível, quando só conhecia as suas larvas e ninfas" (MÜLLER, 1878c, p. 125).

Uma curiosa observação realizada pelo autor é a descrição de uma espécie de tricóptero que residia em uma planta das bromeliáceas, família botânica com distribuição neotropical e da qual apenas no Brasil ocorrem cerca de 40 gêneros e 1.200 espécies (SOUZA, LORENZI, 2008, p. 177).

A descrição que Müller realiza sobre a família das bromélias é transcrita a seguir:

Entre as folhas das Bromeliaceaes que abundam como para$\operatorname{sitas}^{64}$ nas árvores do mato virgem, ajunta-se e conserva-se por muito tempo água de chuva, assim como uma variedade extraordinária de substâncias vegetais: fragmentos de ramos, folhas, flores, frutos e sementes, que às vezes ali germinam; não é raro ver-se um pezinho de gissara ${ }^{65}$ elevando-se entre as folhas de alguma Bromélia; encontra-se enfim, nutrindo-se daqueles restos vegetais mais ou menos

\footnotetext{
64 Bromélias são epífitas, isto é, utilizam as árvores como suporte e não as prejudicam. 65 Este pezinho de "gissara", a qual Müller se refere, trata-se de uma das designaçôes populares para a palmeira Euterpe edulis, nativa do Brasil, conhecida também como palmito juçara (LORENZI, 2010).
} 
apodrecidos ou transformados em húmus, uma multidão de animais terrestres e aquáticos: Planárias (Geoplana ${ }^{66}$ ), Hirudineas $^{67}\left(\right.$ Clepsine $\left.^{68}\right)$, oniscos ${ }^{69}$, centopéias, formigas, larvas de dípteros, de lavadeiras ${ }^{70}$, pererecas, etc. Um dia lembrei-me que, como tantas outras larvas aquáticas, também podia viver naqueles tanques aéreos a larva de algum Trichoptero. Tomei o facáo e fui ao mato. Mal tinha cortado e examinado uma dúzia de bromélias, encontrei logo uma casa de Trichoptero [...] (MÜLLER, 1878c, p. 114).

Müller foi um grande estudioso das bromeliáceas da Mata Atlântica. No excerto, cita a principal característica da família: capacidade de acumular água de chuva em "tanques" formados pela disposição de suas folhas. Porém, a ideia de bromélias serem plantas parasitas tal qual é colocado já não é mais considerada. $\mathrm{Na}$ verdade, são epífitas que se utilizam dos troncos de árvores apenas como suporte para seu desenvolvimento, não se aproveitando de nenhum recurso de sua "hospedeira", uma relação ecológica harmônica denominada de "inquilinismo".

$\mathrm{O}$ artigo propóe novas categorias para a classificação taxonômica dos tricópteros, bem como estabelece novos gêneros e espécies que, apesar de muitos dos termos utilizados para a descrição das casas, bem como sua classificação taxonômica dentro de famílias e gêneros já ter caído em desuso ou ter sido alterada,

\footnotetext{
${ }^{66}$ Geoplana é um dos 16 gêneros da família Geoplanidae. São planárias terrestes, encontradas em florestas tropicais. (BRUSCA; BRUSCA, 2007).

${ }^{67}$ Hirudinea é uma classe do filo Anellida, representada pelas conhecidas sanguessugas, as quais foram amplamente estudadas por Müller, visto que seu doutorado em Filosofia foi obtido com um trabalho sobre as sanguessugas encontradas nos arredores de Berlim.

${ }^{68}$ Clepsine é um gênero da classe da Hirudinea (BRUSCA; BRUSCA, 2007).

${ }^{69}$ Onisco é um dos nomes populares dos isópodos terrestres. Isopoda é uma ordem do subfilo Crustacea do filo Artrhopoda (BRUSCA; BRUSCA, 2007).

${ }^{70}$ Larvas de lavadeiras são imaturos (ninfas) aquáticas de libélulas (ordem odonata).
} 
permanecem originais no sentido de contribuírem com uma área até então sem nenhum estudo no Brasil.

Outro ponto interessante é que ao apresentar a descrição das casas da família Leptocerideae, Müller inclui nesta o gênero Grumicha ${ }^{71}$. Entre o tempo do envio do original ao Museu e sua publicação, ele percebeu que havia cometido um erro na classificação taxonômica e envia uma errata, devidamente incorporada junto das estampas, provavelmente por ser a última parte da revista a ser impressa e não necessitar da reformulaçáo do artigo. É curioso observar a humildade de Müller em assumir publicamente seu erro, bem como em esclarecer ao leitor a devida correção. A errata enviada por Müller é a seguinte:

Por um descuido deixei de examinar no ano passado os palpos dos machos e por isso coloquei erradamente a Grumicha na família dos Leptocerideas (ou Mystacideas), seguindo o exemplo de Hagen que a chama de Leptocerus grumicha. $\mathrm{O}$ inseto perfeito concorda nos esporóes das tíbias e outros caracteres com o gênero Barypenthus, de que Burmeister ${ }^{72}$ descreveu duas espécies provenientes de Nova Friburgo. Ora, esse gênero, a que a Grumicha parece ser aliada foi também colocada novamente na família dos Leptocerideas por Mac-Lachlan. O meu erro provém da nímia confiança que pus nesses dois distintos entomologistas, que hoje são as primeiras autoridades no tocante aos Tricópteros (MÜLLER, 1878c, p. 115).

\footnotetext{
${ }^{71}$ As casas construídas pelas larvas eram chamadas de grumixás pelos indígenas. De acordo com Rafael et al. (2012, p. 614), "curubixá” ou "grumixá” significa "lugar onde vive o menino", o que indica que os indígenas possuíam conhecimento de que os habitantes das casinhas eram as larvas, forma jovem do inseto. Müller utilizou esse nome para a descrição do gênero.

72 Hermann Burmeister (1807-1892) foi um naturalista alemão que já havia passado pelo Brasil.
} 


\subsection{Estudos sobre dípteros}

Na produção científica de Müller, excluindo o artigo publicado nos Archivos, há outros quatro sobre a ordem dos dípteros (Quadro 8), exclusivamente, de metamorfose (SCHLENZ; FONTES; HAGEN, 2012, p. 48-61). Nesta ordem, todos os organismos passam por metamorfose completa ou holometábola, tal qual a dos lepidópteros e tricópteros.

Quadro 8 - Principais características da ordem Diptera

\begin{tabular}{|c|c|c|}
\hline $\begin{array}{l}\text { Etimologia: di significa duas e } \\
\text { pteron, asa. As referências sáo } \\
\text { ao número de asas funcionais } \\
\text { encontradas, em quase todos os } \\
\text { membros adultos. } \\
\text { É uma das ordens mais antigas } \\
\text { entre os insetos holometábolos e } \\
\text { também uma das mais estudadas, } \\
\text { porque muitas espécies sáo } \\
\text { vetores de organismos que } \\
\text { causam doenças nos animais e } \\
\text { nos seres humanos. }\end{array}$ & $\begin{array}{l}\text { Compreendem } \\
\text { cerca de } 153.000 \\
\text { espécies descritas, } \\
\text { distribuídas em } 160 \\
\text { famílias. No Brasil } \\
\text { estão presentes cerca } \\
\text { de } 8.700 \text { espécies. }\end{array}$ & $\begin{array}{l}\text { O comprimento } \\
\text { dos adultos varia de } \\
0,5 \mathrm{~mm} \text { a } 60 \mathrm{~mm} \text {. } \\
\text { Na cabeça são } \\
\text { encontrados olhos } \\
\text { compostos, peças } \\
\text { bucais e antenas } \\
\text { como apêndices. }\end{array}$ \\
\hline
\end{tabular}

Fonte: Rafael et al. (2012, p. 702).

Nos Archivos, Müller publicou apenas um trabalho sobre dípteros, subdividido em quatro partes: $A$ metamorphose de um insecto diptero. Este artigo contém grande número de ilustraçôes: a primeira parte inclui 16 figuras (Estampa IV); a segunda, 20 (Estampa V); a terceira, 07 (Estampa VI); e a quarta 25 (Estampa VII).

Na primeira parte, Descripção do exterior da larva (MÜLLER, 1879b, p. 47-56), o autor fornece dados referentes ao encontro da larva do inseto: "No ribeirão do Garcia, tributário do rio Itajahy (província de Santa Catarina) e nos seus afluentes, os ribeiróes do 
Jordão e do Café, vive pegado às pedras das mais rápidas correntezas um animal curiosíssimo (MÜLLER, 1879b, p. 46). ${ }^{73}$

O animal era "curiosíssimo" pois apresentava características desconhecidas à época para os dípteros, posteriormente analisadas pelo naturalista nas quatro partes do trabalho. $\mathrm{O}$ autor chega a comentar que enviou exemplares secos do animal a diversos naturalistas abalizados ${ }^{74}$, que não conseguiram identificá-lo, nem mesmo pronunciar-se sobre a classe na qual pudesse ser inserido. Até mesmo o autor da Biblioteca Entomológica, que recebeu um exemplar remetido por Müller, não conseguiu descrevê-lo, encaminhando ao naturalista de Santa Catarina o seguinte comentário: "Myriapede 75 não é, e entre os insetos não se conhece coisa alguma, que lhe seja semelhante" (MÜLLER, 1879b, p. 47).

$\mathrm{O}$ autor da Biblioteca Entomológica é Hermann August Hagen (1817-1893). Hagen publicou em 1862 (vol. 1) e 1863 (vol. 2) o livro Bibliotheca entomologica. Die Litteratur über das ganze Gebiet der Entomologie, bis zum Jahre ${ }^{76}$. De acordo com Fontes (2007), Hagen foi uma autoridade no estudo taxonômico de insetos, especialmente cupins. Foi convidado por Louis Agassiz a emigrar da Prússia para os EUA, onde se integrou ao Museum of Comparative Zoology da Universidade de Harvard, em Cambridge, e fundou o Departamento de Entomologia da Universidade. Mais tarde, Müller recorreu a ele para ajudá-lo na identificação dos cupins de Santa Catarina.

\footnotetext{
73 Apesar de fornecer a localização da larva, Müller sugere que esta também pode ser encontrada em regióes análogas, em outras províncias do Brasil, além da de Santa Catarina.

74 O termo utilizado se refere a pessoas competentes, notáveis e ilustres.

75 Myriapoda é um subfilo dos artrópodes no qual se incluem as classes Chilopoda, Diplopoda, Symphyla e Pauropoda (BRUSCA, BRUSCA, 2007).

76 Disponível em: https://archive.org/search.php?query=bibliotheca $\% 20$ entomologica. Acesso em: 15 jun. 2014.
} 
No primeiro momento, Müller observou que o inseto "anda lentamente entre as pedras"; fato que o levou a pensar se tratar de exemplares de crustáceos isópodes do gênero Idera, que já havia estudado trinta anos antes na costa do Mar Báltico.

Provavelmente Müller supôs tratar-se de isópodes, pois estes não possuem carapaça, tal qual a larva observada que apresentava corpo mole. Um exemplar comum de isópode é o tatuzinho de jardim. Quanto ao gênero supracitado pelo autor, uma consulta a especialista ${ }^{77}$ mostrou que não foi possível encontrar referências. É possível que tenha havido um erro de grafia, ousandose inferir que se trata, na verdade, do gênero Idothea, com o qual Müller já possuía familiaridades em outros estudos, a exemplo de Für Darwin (1864). Devido à localização que Müller fornece (mar Báltico), a dedução de que a espécie é a Idothea baltica (Pallas, 1772) ganha mais força.

A partir da primeira hipótese levantada, o autor compara sua "larva" com os crustáceos e percebe que a nova espécie apresenta o corpo dividido em seis segmentos, ao contrário dos isópodes, que possuem nove segmentos (um na cabeça, sete no tórax e um no abdômen). Notou também que no exemplar em questão, encontravam-se, ao lado desses segmentos, espinhos laterais; e em alguns casos, também espinhos dorsais, que apresentavam variedades entre os espécimes: alguns apresentavam um par em cada segmento, podendo, contudo, faltar em um ou mais segmentos, ou até completamente. ${ }^{78}$

Müller analisou 138 exemplares e comparou a frequência dos espinhos dorsais, conforme o excerto: "Examinei estes espinhos em 138 animais maiores e menores; 92 tinham os seis pares

\footnotetext{
77 Entomólogo Dr. Luiz Roberto Fontes.

78 Nos animais em que faltavam os espinhos dorsais, frequentemente também faltavam ou eram rudimentares os laterais (MÜLLER: 1879b, p. 49).
} 
completos, em dois faltavam os do segmento oral, em 14 os do segmento oral e anal; em três os dos primeiro, quinto e sexto segmentos; enfim, 27 animais eram destituídos inteiramente de espinhos dorsais" (MÜLLER, 1879b, p. 48).

A análise foi tão minuciosa que, dos 138 "animais maiores e menores" (separação baseada no comprimento das larvas), Müller os classificou quanto ao comprimento: examinou em separado 24 animais que ainda náo haviam chegado "nem a metade do seu comprimento definitivo" e notou que apenas sete eram munidos dos espinhos dorsais, levando-o a concluir que a ausência ou presença destes espinhos variavam em relação ao comprimento do animal e ao seu estágio de desenvolvimento, visto que nos espécimes maiores analisados, 67 apresentavam espinhos dorsais e apenas 20 não os possuíam.

Dentre todas as características encontradas e descritas no artigo, a existência de brânquias não deixou dúvidas ao autor de que o animal fosse a larva de algum inseto (MÜLLER, 1879b, p. 55). Porém, em qual ordem poderia ser incluído?

Ora, sendo ápode [sem patas], é excluído das ordens dos Ortópteros, Neurópteros, Tricópteros, Lepidópteros e Hemípteros, cujas larvas possuem todos os três pares de pernas torácicas. Nem tampouco poderá entrar na ordem dos Hymenópteros, cujas larvas, quando ápodes, carecem ao mesmo tempo do orifício anal; além disso, não há larva de Hymenóptero vivendo na água e dotada de brânquias. Entre os coleópteros há larvas aquáticas, cujo abdômen é guarnecido de um e outro lado da face ventral de belíssimas brânquias aeríferas na família das Pernídeas; porém essas larvas não são ápodes, há outras larvas de coleópteros privadas de pernas, mas estas todas vivem fora da água. Restam pois unicamente os Dípteros; nesta ordem todas as larvas são ápodes, muitas são aquáticas e entre estas não escasseiam as dotadas de brânquias aeríferas. Assim, já pelo exame do exterior, fica sumariamente provável ser o animal a larva de algum díptero (MÜLLER, 1879b, p. 57). 
No excerto supracitado, é interessante observar como o autor constrói e desconstrói suas hipóteses a fim de validar o conhecimento científico produzido. Depois de toda a observação microscópica, comparaçáo, medida de exemplares, coleta e análise de dados em conjunto ao seu conhecimento acerca das ordens de insetos, chegou à ordem dos dípteros através da eliminação das outras hipóteses que levantou.

Porém, apesar de inseri-lo na ordem, restavam algumas dúvidas, como a presença de ventosas e a disposição das brânquias, fatos inteiramente novos à época, acerca da larva dos dípteros; e o número de segmentos também era um mistério ${ }^{79}$, uma vez que todas as larvas conhecidas possuíam cerca de 13 ou 14 segmentos (cabeça, três torácicos e nove abdominais).

Os questionamentos que Müller levantou o levam a estudar a anatomia e a metamorfose da larva e na segunda parte do artigo ele apresenta a Anatomia (MÜLLER, 1879b, p. 57-63), iniciando sua descrição pela boca, seguido das mandíbulas, maxilas, canal intestinal e órgãos digestivos e vasos urinários.

Quando analisa os vasos urinários (atualmente designados túbulos de Malpighi), insere sua larva em outra seção dentro da ordem dos dípteros, na família dos tipulários. A inserção na família se deve à observação e eliminação de hipóteses através de suporte na literatura consultada. Ele encontrou cinco vasos urinários na larva, o que se tornava um caso raro entre os insetos, que os possuíam em número de três. De acordo com a bibliografia consultada por ele, este número só havia sido observado nos grupos dos culicide e dos tipulinos noctuiformes (psicodídeos), ambos

\footnotetext{
79 Quanto aos segmentos, Müller se expressa da seguinte forma: "Uma larva de inseto com seis segmentos somente é um verdadeiro paradoxo; falta mais da metade para completar o número normal" (MÜLLER, 1879b, p. 56).
} 
inseridos nas tipulárias ou dípteros nematóceros. Nesse sentido, classifica a larva como um díptero da família dos tipulários.

Müller utiliza como consulta o livro Lehrbuch der vergleichenden anatomie der wirbellosen Thiere (1848), de autoria do naturalista e zoólogo alemão Carl Theodor Ernst Siebold (18041885). Na página 626 (SIEBOLD, 1848), encontra-se a referência utilizada por Müller: Die Dipteren enthalten fast durchweg vier lange Malpighische Gefässe, nur die Culiciden und Psychoden sind ausnahmsweise mit fünf Harnkanälen ausgestattet. (Quase todos os dípteros possuem quatro longos vasos de Malpighi, apenas Culicidae e Psycholinos são equipados com cinco vasos).

Na terceira parte (MÜLLER, 1879b, p. 65-74), Müller descreve mais detalhes acerca da larva, observando que esta possuía características comuns ao grupo dos dípteros: sistema de traqueias ou vasos aeríferos, que se comunicavam com o ambiente por meio de espiráculos, dispostos simetricamente por pares, ocupando as laterais do corpo.

Há uma discussão sobre o sistema traqueal das larvas importante de ser citada, visto que se nota novamente o diálogo com as ideias de Darwin, conforme os dois excertos a seguir:

[...] os vasos aeríferos não comunicam diretamente com o ar, sendo fechados de todos os lados; neste caso o ar contido nos ditos vasos não pode ser renovado diretamente, $\mathrm{e}$ só através das paredes daqueles vasos que se ramificarem, seja na superfície do corpo, seja em brânquias aeríferas, o ácido carbônico resultante do processo de respiração poderá ser substituído pelo oxigênio dissolvido no fluido ambiente (MÜLLER, 1878b, p. 65).

Desde que se principiou a aplicar as ideias de Darwin aos insetos, surgiu necessariamente esta questáo: qual dessas duas formas do aparelho respiratório devia ser considera- 
da como primitiva, e como dela podia ser derivada a outra (MÜLLER, 1878b, p. 66).

Observou-se até aqui que, após o lançamento de Origin, a evolução se tornou a teoria mais aceita para explicar a diversidade biológica. Porém, muitos aspectos específicos intrincados à teoria de Darwin se tornaram motivos de controvérsia durante os oitenta anos seguintes, levando a uma variedade de "evolucionismos" (GUALTIERI, 2008). Apesar de muitas das ideias darwinianas não terem sido aceitas no mundo científico da época, o estudo dos invertebrados é considerado a "especialidade científica" que mais se utilizou do conjunto das teorias de Darwin para explicar as variaçóes e os ciclos de vida do grupo, bem como na realização de estudos comparativos (GUALTIERI, 2008, p. 204).

A essa discussão específica acerca da respiração dos insetos, Müller pontua duas correntes opostas: de um lado encontra-se Karl Gegenbaur (1826-1903), do qual Müller diz que é um "dos juízes mais competentes em questóes morfológicas e filogenéticas" (MÜLLER, 1879b, p. 66). Gegenbaur (1859), em sua obra Grundzuge der vergleichenden Anatomie, considera que os vasos aeríferos teriam tido uma função primitiva hidrostática para o animal. Esses vasos se distribuíam pela superfície do corpo ou nas brânquias e posteriormente teriam servido também à respiração. A partir do momento em que se completa a metamorfose e os insetos saem da água, as brânquias se perderiam e os vasos aeríferos teriam sofrido ruptura em espiráculos, fazendo com que estes permanecessem abertos, ao contrário da condição anterior ${ }^{80}$ (GERGENBAUR, 1859, p. 253-263).

80 Gergenbaur, K. Grundzuge der vergleichenden Anatomie (Curso básico de anatomia comparada). Leipzig, 1859. Digitalizado para Internet Archive em $2011 \mathrm{com}$ apoio da Escola de Medicina de Harvard. Disponivel em: <http://www.archive. org/details/grundzgederverOOgege>. Acesso em: 18 jun. 2014. 
A corrente oposta era defendida por Paul Mayer (18481923), Johan Palmen (1845-1919) e o próprio Müller, apoiados nos trabalhos de Palmen. Em seus estudos acerca da questáo, Palmen observou que todas as larvas aquáticas já possuíam espiráculos, ainda que fechados, e que estes não têm relação com as brânquias traqueais. Ele observou que os vasos aeríferos existem nos estágios mais simples do desenvolvimento e que estes, ainda que rudimentares, possuem papel crucial no despojamento do tegumento das larvas, o que o levou a concluir que tais fatos só são explicáveis se tais larvas fossem descendentes de formas com traqueias abertas (PALMEN, 1877, p. 55-65).

Em toda a descrição dos vasos aeríferos do inseto realizada por Müller, nota-se um apoio às proposiçôes de Palmen e Mayer, que aceitavam a questão da herança, em contraste a uma forte oposição a Gergenbaur. Um dos pontos mais controversos da teoria de Darwin era a herança de caracteres, a qual Müller também aceitava. A herança de caracteres sustenta que uma característica obtida por um ser vivo durante sua existência - pelo uso ou desuso de alguma parte do corpo ou por mutilaçóes - seria transmitida a seus descendentes.

Exemplo dessa aceitação de Müller ao conceito da herança dos caracteres adquiridos também é encontrada em sua monografia sobre cupins: nela, o autor discute a origem das asas desses insetos, contrariando a opiniáo da época de que estas provinham das brânquias traqueais ao afirmar que eram expansôes laterais dos notos torácicos. Ele discute que expansōes laterais não são adquiridas por seleção natural, mas sim uma herança dos ancestrais, que viviam sob condiçóes externas e que utilizavam a respiração em habitats úmidos (FONTES, 2007).

Em outro ponto da leitura (MÜLLER, 1879b, p. 69), em que demonstra a diferença entre o último par de troncos 
iniciais aeríferos em oposição aos demais que eram fechados ${ }^{81}$, o que constituía para Palmen o "ponto" de despojamento da membrana íntima dos vasos aeríferos, Müller faz uma "provocação" aos companheiros naturalistas que aceitavam a ideia de um Deus criador e de uma natureza criada sob a tutela divina.

Há aí uma dificuldade muito séria para os adversários de Darwin, que não admitem a transformação das espécies, e sim, como Agassiz, as consideram como pensamentos encarnados do criador. No entender deles, desde o princípio o Criador teria concebido um plano típico e inalterável para cada grupo de seres orgânicos; as partes rudimentares e sem função só existiriam por assim o exigir o tal plano ou, como também disseram, para guardar a simetria do organismo. Pouco ou nada vale esta explicação das partes rudimentares; mas nem mesmo ela é aplicável ao presente caso. Como poderia o plano típico exigir que o último par de troncos iniciais seja aerífero e todos os mais rudimentares, se a todos eles cabe a mesma função, resultando daí uma simetria evidente? Para eles, pois, haverá aqui um capricho inexplicável do Criador. Para os partidários de Darwin, pelo contrário, o fato é muito significativo e de fácil explicação, fornecendo até uma das provas mais frisantes da verdade do transformismo (MÜLLER, 1879b, p. 69).

O termo "transformismo", utilizado por Müller no excerto, refere-se às mudanças sofridas por determinada espécie pelo mecanismo da seleção natural proposto por Darwin, e não ao significado atribuído à época por parte dos naturalistas franceses que utilizavam o termo para referir-se a Lamarck.

Müller era um ateu convicto que encontrou na teoria de Darwin a explicação científica para as causas da natureza, ao contrário de muitos naturalistas do período, que buscavam aliar as

81 Impérvios no original. 
ideias de Darwin com a supremacia de um Deus criador, como fazia até mesmo o próprio diretor do Museu Ladislau Netto, conforme o excerto:

A nova doutrina, de verdadeira e sedutora que é, antes de vencer, convence. Conquistadora da razão, ela oferece, pela maneira rápida com que se assimila no seio da sociedade, a mais eloquente prova de sua perfeição $[\ldots]$ sem pretender provocar conflitos na órbita da religiáo [...], antes, ao contrário, submetendo-se a seu irresistível domínio (NETTO, 1882, p. 148 apud GUALTIERI, 2008, p. 50).

Louis Agassiz (1807-1873) era adepto da teoria de Cuvier (1769-1832), sobre o catastrofismo, que buscava explicar pela análise dos fósseis e dos estratos geológicos, as diferentes espécies de seres vivos. Tanto Agassiz como Cuvier acreditavam que os seres vivos passavam por ciclos de criaçóes e de extinções (grandes catástrofes) controladas por um Criador soberano. O filho de Agassiz, Alexander, ao contrário do pai, era adepto do evolucionismo, sendo que sua adesão, conforme Darwin conta, deve-se à leitura do livro de Müller, bem como pela correspondência trocada entre os dois naturalistas, segundo este excerto:

Alex Agassiz acaba de me fazer uma visita junto com sua esposa. Ele tem estado na Inglaterra dois ou três meses, e agora está indo fazer um tour no continente pra ver todos os zoologistas. Nós gostamos muito dele; é um grande admirador seu, e me contou que foi sua correspondência e seu livro que o levaram a acreditar na evoluçáo. Isto deve ter sido um grande golpe para o seu pai o qual, como ele me falou, está muito bem, e táo vigoroso que pode trabalhar duas vezes mais que ele (o filho) (ZILLIG, 1997, p. 185).

Além dos vasos aeríferos, Müller fornece uma descrição acerca da musculatura e do sistema nervoso da larva, trazendo ao 
final do artigo um resumo de suas observaçóes, bem como suas consideraçôes.

Quanto à posição sistemática, sua larva é a de um inseto díptero aliado ao grupo dos Culicideos, os quais têm em comum o número dos vasos malpighianos (05) e serem descendentes de formas que respiravam o ar por meio de espiráculos situados no extremo posterior do abdômen, conforme espécies do gênero Culex. Quanto à segmentação, Müller conclui que o segmento oral deverá compreender no indivíduo adulto um cefalotórax correspondendo à cabeça e tórax e mais o primeiro segmento abdominal de outras larvas; os segmentos intermediários compreenderão no adulto um único segmento abdominal (através da disposiçáo do sistema respiratório e nervoso) e que os quatro segmentos abdominais corresponderáo ao segmento anal no indivíduo adulto (MÜLLER, 1879b, p. 73-74).

$\mathrm{Na}$ quarta parte, Crisalida e insecto perfeito (MÜLLER, 1879b, p. 75-85), o autor descreve a forma de metamorfose crisálida ou pupa do inseto, destacando a presença de chifres protorácicos, também comuns em outros dípteros e em Culex (MÜLLER, $1879 b$, p. 76), em que a estrutura serve para a respiração.

Referente à última fase da metamorfose, imago ou indivíduo adulto, Müller náo conseguiu observá-los próximos aos lugares em que passam os primeiros estágios de vida, tampouco pôde observar o processo natural da metamorfose, visto que, após removidas as crisálidas de seu lugar de origem, morriam em curto período (MÜLLER, 1879b, p. 79-80). Para poder examinar a imago, retirou-as artificialmente das crisálidas, um processo, segundo ele, de extrema facilidade, devido às asas já estarem tenras, podendo desdobrá-las facilmente.

A principal diferença apontada para os adultos é a presença de dois tipos de fêmeas: fêmeas melíferas e hematófogas ${ }^{82}$ na

${ }^{82}$ No original utiliza-se o termo em desuso, "sanguessuga". 
mesma espécie, prevalecendo o comportamento melífero, conclusão que chegou através do exame de 20 fêmeas, em que 13 eram melíferas e sete hematófagas (MÜLLER, 1879b, p. 80).

Por se tratar de uma espécie ainda não descrita na literatura, Müller a nomeia como Paltostoma torrentium ${ }^{83}$, pois estava inserida no gênero Paltostoma da família dos Blepharocerídeos, de acordo com classificação ${ }^{84}$ realizada pelo professor Frederico Brauer (1832-1904), da Universidade de Viena, na Áustria. (MÜLLER, 1879b, p. 85).

Essa descrição peculiar levou outros naturalistas no início do século XX a pesquisarem a família Blepharoceridae; exemplo de Adolfo Lutz, após conhecimento prévio do trabalho de Müller (LUTZ, 1920). De acordo com Lutz, "o conhecimento das Blepharoceridae brasileiras limitava-se a um trabalho de Fritz Müller", com a descrição de uma espécie: Curupira torrentium ${ }^{85}$. Outros pesquisadores, como o Dr. Charles Chilton, da Nova Zelândia, e Cordeiro, da Inglaterra, também descreveram novas espécies da família baseados nas descrições de Müller (CHILTON, 1920, p. 277-278). Além disso, examinando The Annals and magazine of natural historia de 1915, observa-se que novas espécies para a família estavam sendo descritas em lugares diversos, como México, Trinidad e Tobago, Colômbia e no continente africano, utilizando como referencial a descrição da larva de Müller como ponto de partida. De acordo com esses

\footnotetext{
${ }^{83}$ Mais tarde Curupira torrentium e atual Kelloggina torrentium Müller.

${ }^{84}$ Brauer classifica o inseto em artigo publicado em Zoologischer Anzeiger (Indicadores zoológicos), n. 51, de 22 de março de 1880, p. 134-135. Neste artigo, faz um resumo sobre o inseto descrito por Müller e o classifica taxonomicamente. O volume pode ser consultado em: <http://biodiversitylibrary.org/page/9456414>. Acesso em: 15 jul. 2014.

85 Lutz descreveu e nomeou 21 espécies dentro da família entre 1920 e 1928. Kelloggina muelleri (anterior Curupira muelleri) é uma homenagem a Müller. (LUTZ, 1920).
} 
anais, Curupira torrentium seria uma espécie intermediária entre dois gêneros: Paltostoma e Kelloggina. De fato, a espécie atualmente é nomeada como Kelloggina torrentium Müller.

Quanto à questão do dimorfismo de hábito em fêmeas (melífera e hematófaga), Lutz afirma que não há conhecimento de fêmeas hematófagas na família. De acordo com este autor, "pode-se considerar errônea a suposição que haja blepharocerídeos sugadores de sangue vermelho" (LUTZ, 1920, p. 23). De acordo com Lutz, devido a Müller não ter observado a metamorfose natural, poderia ter se equivocado quanto às fêmeas observadas.

Pensando no conjunto das obras de Müller, é possível notar que sua observação referente aos dois tipos de fêmeas, melíferas e hematófagas, encaixavam-se à sua visão de mundo e ao processo de seleção natural que tanto defendia, não levando o naturalista a se questionar se de fato as fêmeas encontradas se inseriam ou não na mesma espécie. Quando estudou os crustáceos que geraram o seu livro Für Darwin, Müller encontrou situação semelhante: havia duas formas de machos adultos para o gênero Tanais: os agarradores, em maior número, dotados de pinças para segurar a fêmea no acasalamento; e os farejadores, em menor quantidade, que possuíam antenas com muitos filamentos olfativos (MÜLLER, 2009, p. 45-53).

A diferença dentro da espécie é explicada pela seleção natural:

O nosso isópodo quelífero Tanais, que em quase todos os particulares de sua estrutura é um animal extremamente notável, forneceu-me um segundo fato digno de mençáo, relativo à teoria da origem das espécies por seleção natural (MÜLLER, 2009, p. 45).

Fornecendo uma explicação sucinta para o dimorfismo sob tal influência: 
Os melhores farejadores venceriam todos os que lhes fossem inferiores nesse respeito, a menos que estes tivessem outras vantagens, tais como pinças mais poderosas, para lhes opor. Os melhores agarradores sobrepujariam todos os guerreiros menos armados, se estes náo lhes opusessem outras vantagens, tal como sentidos mais aguçados. Compreende-se como dessa maneira todos os estados intermediários menos favorecidos no desenvolvimento de filamentos olfativos, ou de pinças, desapareceriam do campo de batalha e duas formas nitidamente separadas, os melhores farejadores e os melhores agarradores, sobrariam como os únicos adversários. No momento, o combate parece decidir-se em favor dos últimos, pois eles superam largamente em número, talvez de uma centena para cada farejador (MÜLLER, 2009, p. 48-49).

O caso das fêmeas melíferas e hematófagas foi publicado posteriormente por Müller na revista Kosmos e republicado em Nature $^{86}$ por seu irmão Hermann. Para ambos, a explicação estava na seleção natural: provavelmente os ancestrais da espécie eram hematófagos. Com o tempo, algumas das fêmeas que precisavam de mais alimentação para a postura dos ovos iniciaram uma nova "dieta", enquanto outras preservaram seus hábitos originais durante várias geraçóes e perdurando.

\subsection{Estudos sobre crustáceos}

Müller foi um grande pesquisador dos crustáceos (Quadro 9). Excluindo-se as publicaçóes encontradas em Archivos, publicou

${ }^{86} \mathrm{O}$ título do artigo é: Explanation of the Female Dimorphism of Paltostoma torrentium (Explicaçóes sobre o dimorfismo das fêmeas de Paltostoma torrentium). 1881. Disponível em: <http://www.nature.com/nature/journal/v24/n610/abs/ 024214d0.html>. Acesso em: 18 jun. 2014. 
outros 26 artigos sobre o tema (SCHLENZ: FONTES; HAGEN, 2012, p. 48-61), bem como seu livro Für Darwin (1864).

Quadro 9 - Principais características da ordem Crustacea

\begin{tabular}{|c|c|c|}
\hline Etimologia: crusta & Apesar de grande & Possuem dois pares \\
significa pele grossa ou & diversidade, o & de antenas, o corpo \\
crosta. Sáo conhecidas & táxon exibe em & dividido em dois \\
cerca de 67.000 espécies, & comum algumas & segmentos (cefalotórax \\
que exibem uma grande & características, como & e abdome) e presença \\
diversidade em relaçáo & o desenvolvimento & de numerosos pares de \\
à morfologia, hábitos, & indireto ou direto & pernas (geralmente cinco \\
habitat e tamanho & com larva náuplio, & ou mais), sendo que \\
corporal. & mandíbulas com & muitos deles apresentam \\
& apêndices geralmente & apêndices birremes \\
& multiarticulados. & adaptados à nataçáo. \\
\hline
\end{tabular}

Fonte: Brusca e Brusca (2007, p. 531).

Conforme ele mesmo comenta na introdução de Für Darwin, seus estudos se iniciaram buscando analisar um grupo de animais sob a influência da teoria proposta por Darwin:

Quando eu li o livro de Charles Darwin sobre a origem das espécies, pareceu-me que um dos meios, e talvez o mais seguro, de provar a veracidade das teses nele desenvolvidas seria aplicá-las, o mais minuciosamente possível, a um determinado grupo de animais (MÜLLER, 2009, p. 1).

Nos Archivos, Müller publicou cinco artigos sobre crustáceos. Desses artigos, quatro foram publicados após sua exoneração do Museu Nacional, ocorrida em 1891. Tal fato se deve ao atraso de publicaçáo que o periódico vinha sofrendo por falta de verbas e também pela troca de gestáo do periódico por conta da aposentadoria do Dr. Ladislau Netto. Durante 1892 a 1893, o Museu foi administrado por Amaro Ferreira das Neves Armond (1854-1944), que publicou o volume VIII, conforme o excerto: 
Só agora aparece à luz da publicidade o volume VIII dos Archivos; vem retardado, sem que caiba à atual administração do Museu responsabilidade alguma desse fato, porquanto data apenas de setembro último o nosso exercício na diretoria geral desta instituição, tendo sido um dos nossos primeiros cuidados providenciar sobre a pronta publicação desta revista, há anos interrompida (ARMOND, 1892, p. 3).

Era comum Müller publicar suas pesquisas nos Archivos e subsequentemente em outro periódico internacional, como a descrição de Elpidium bromeliarium, que figura no quarto volume de 1879 e também na revista Kosmos de 1879/188087. Porém, dois artigos que figuram nos Archivos de 1892 não são estudos recentes, mas sim reedições de publicaçóes de cerca de uma década antes, visto que sua descrição de Palaemon potiuna, Müller foi originalmente publicada em 1880 na Zoologischer Anzeiger de $1880^{88}$, e a descrição de Atyoida potimirim, Müller em 1881 na Kosmos $^{89}$.

Os cinco artigos tratam, de forma geral, da descrição de novas espécies de crustáceos, bem como buscam fornecer dados a favor da seleção natural, exemplo da metamorfose abreviada encontrada em espécies de caranguejos e camaróes que viviam em águas de grande correnteza, em que o autor se utiliza do conceito de seleção natural como a causa de formas variantes que eclodem dos ovos, como jovens ativos capazes de lidar com essa adversidade.

\footnotetext{
Wasserthiere in Baumwipfeln Elpidium bromeliarium. Kosmos, Leipzig, 1879/1880, 6, p. 386-388. (Animais aquáticos em copas de árvores. Elpidium bromeliarium).

88 Palaemon potiuna. Ein beispiel abgekürzter verwandlung. Zoologischer Anzeiger 1880, 3(52), p. 152-157. (Palaemon potiuna. Um exemplo de metamorfose abreviada).

${ }^{89}$ Atyoida potimirim, eine schlammfressende süsswassergarneele. Kosmos, Leipzig, 1881, 9, p. 117-124. (Atyoida potimirim, um camarão de água doce comedor de lama).
} 
Preferiu-se, nesta seçáo, subdividir seus estudos em duas vertentes: crustáceo habitante de bromélia, devido a essa particularidade específica, e metamorfose, morfologia e descriçāo de crustáceos.

\subsubsection{Crustáceo habitante de bromélia}

Os microecossistemas mantidos pelas bromélias são chamados de fitotelmata (SOPHIA, 1999). No volume de 1879, Müller publica: Descrip̧ão de Elpidium bromeliarium crustaceo da familia dos cytherideos ${ }^{90}$. Este habitante de fitotelmata das bromélias foi descrito pela primeira vez por Müller e na literatura é citado como o primeiro estudo sobre a carcinofauna brasileira (BOOS et al., 2012; PEREIRA, 2013).

Müller nomeia a espécie em homenagem a um fóssil da família encontrado nas camadas silurianas ${ }^{91}$ da Bohemia ${ }^{92}$, espécie de Elpes pinguis, assemelhada à encontrada em Santa Catarina, em relação ao tamanho das conchas ${ }^{93}$.

O autor descreve minuciosamente a espécie, oferecendo medidas das conchas, descrição de olhos e antenas, peças bucais,

90 Os cytherideos são incluídos atualmente na ordem Podocopida, superordem Podocopa, subclasse Ostracoda, classe Maxillopoda (BRUSCA; BRUSCA, 2007).

91 O período siluriano compreende entre cerca de 44 milhóes e 416 milhóes de anos atrás e é subdividido pelas épocas: Llandovery (a mais antiga), Wenlock, Ludlow e Pridoli (a mais recente). De acordo com Soares (s.d) são registrados os primeiros recifes de coral e aparecimento dos peixes ósseos e cartilaginosos. Além disso, há registro de fósseis de plantas avasculares em ambiente continental, juntamente com fósseis de artrópodes. Disponível em: http://www.rc.unesp.br/museupaleonto/siluriano.htm. Acesso em: 24 out. 2014.

92 A região da Boêmia é uma das 14 que integram a República Tcheca.

93 Os ostracodes, subclasse na qual se incluem os cytherídeos, possuem o corpo envolvido por uma carapaça calcária bivalve. Esta carapaça é trocada pelo processo de ecdise ou muda, típico dos artrópodes, para permitir o crescimento do animal. A principal diferença entre as conchas dos ostracodes e a dos moluscos bivalves, é que a concha dos moluscos apresenta linhas de crescimento, pois ela cresce com o corpo do animal. Como os ostracodes trocam periodicamente sua concha ao crescer, não apresentam tais linhas (COIMBRA; BERGUE, 2004). 
pernas e apêndices caudais, bem como do aparelho genital masculino e feminino. Também são descritas as medidas dos ovos, fornecendo ao final do artigo um resumo taxonômico das características encontradas, ressaltando o porquê da proposição de um novo gênero para a família dos Cytherídeos. Além da morfologia Müller fornece informaçóes que poderiam ser consideradas contribuiçôes ao campo da Ecologia, visto que se referem à associação de fauna às bromélias, bem como trata da dispersão de Elpidium para outras bromélias por meio de insetos polinizadores, conforme se vê a seguir:

O Elpidium é quase o único entre os numerosos visitantes e habitantes das Bromélias, que nelas nasce e morre. Muitos animais vão visitar as bromélias, seja para se agasalharem, seja para se nutrirem das substâncias orgânicas, que entre as suas folhas se acumulam, seja enfim para ali se depositarem os seus ovos. [...]. Outras espécies vivem lá como larvas, saindo depois de concluída a sua metamorfose, como sejam as pererecas e vários insetos Orthopteros (Agrionideos ${ }^{94}$ ), Neuropteros, Trichopteros, Coleopteros (Parnideos) e Dipteros (Culuideos), Tipulideos, Syraphideos e outros. Nem para aqueles visitantes nem para estas larvas há dificuldade alguma em explicar a sua estada nas Bromélias. Com o Elpidium o caso é diferente. Não podendo esses pequenos Ostracodes migrar de uma bromélia e muito menos ainda de uma árvore a outra, como é que náo obstante isso podem eles estabelecer novas colônias? Eles não poderão fazer as viagens necessárias senão aderindo ao corpo de qualquer visitante das bromélias. Apesar de assim parecer abandonada ao acaso a sua transmigração, ela se faz com a mesma

\footnotetext{
94 Apesar de Müller incluir a família dos Agrionideos em Orthoptera, atualmente ela se insere como família da ordem Odonata, na qual se incluem as libélulas. São encontrados ao longo de rios e riachos. No Brasil são representados pelos gêneros Hetaerina e Mnesarete.
} 
regularidade com que o pólen das flores é transportado de uma planta a outra pelos insetos pronubos, como prova o fato de quase não haver bromélia sem a sua colônia de Elpidium (MÜLLER, 1879a, p. 33-34).

Roquette-Pinto, na sua obra Ensaios brasilianos, também atribui a Müller o início das pesquisas sobre a fauna das bromélias, conforme o excerto:

É a fauna das Bromeliáceas - uma das interessantíssimas descobertas de Fritz Müller. Nos vasos esverdeados que as folhas das bromélias compóem, junta-se água suficiente para manter a vida e permitir a evolução de muitas formas. Sabe-se, agora, que são ótimos viveiros de mosquitos. Nesses pequenos aquários, suspensos entre os ramos das grandes árvores, Fritz Müller descobriu, em 1878, animais que ninguém seria capaz de imaginar ali tivessem fixado domicílio. Entre eles uma pequena rã, cuja fotografia mandou a Darwin em 1879, fêmea que carregava no dorso os ovos em via de desenvolvimento. Em todo caso, insetos ou răs compreende-se, sejam encontrados naquelas alturas. Mas..., um crustáceo de tipo fóssil? Pois foi essa a grande, a enorme surpresa que teve o mestre (ROQUETTE-PINTO, 1941, p. 32-33).

Até os dias atuais, esse trabalho de Müller, bem como a descrição de sua espécie-modelo, é utilizado por especialistas para caracterizar novas espécies (PEREIRA, 2013), e é também lembrado como o primeiro estudo em ambientes fitotelmáticos (SOPHIA, 1999).

Elpidium bromeliarium é inserido no táxon Ostracoda, superordem Podocopa, subfilo dos crustáceos, organismos que possuem como caracteres distintivos algumas das características descritas por Müller como carapaça bivalve, ramos caudais presentes, e olho naupliar simples mediano (também chamado de olho maxilopodiano) (BRUSCA; BRUSCA, 2007, p. 572-573). 
$\mathrm{Na}$ década de 1970, esse gênero foi revisado por Pinto e Purper (1970), identificando a ocorrência da espécie bem como sua distribuição em três estados: Rio Grande do Sul, Santa Catarina e Espírito Santo.

Pereira (2013), que realizou pesquisa na própria regiáo em que Müller identificou a espécie pela primeira vez (Vale do Itajaí-SC), buscou identificar novas espécies bromelícolas para o gênero, bem como contribuir com estudos sobre sua ocorrência e distribuição. Nesse trabalho, a autora localiza três espécies em Santa Catarina, a saber: Elpidium bromeliarium (já descrita por Müller) e duas novas espécies, nomeadas por ela de Elpidium coimbrai, Pereira e Elpidium fritzmulleri, Pereira, a última com epíteto em homenagem ao naturalista.

$O$ gênero Elpidium frequentemente está associado ao estudo de fitotelmata (KRÜGEL, 1993; SOPHIA, 1999; LOPEZ et al. 2005). A dispersão desses crustáceos para outras bromélias sob ação de agentes polinizadores, conforme Müller relatou, também é confirmada pela adesão ao tegumento de répteis e anfíbios (LOPEZ et. al., 2005), incluindo que muitos passam pelo trato digestivo de vertebrados saindo ilesos devido à carapaça que possuem (LOPEZ et. al., 1999).

\subsubsection{Metamorfose, morfologia e descrição de crustáceos}

Apesar da grande heterogeneidade de crustáceos, todos compartilham de um caráter comum, que é o estágio larval de náuplio. Espécies que possuem ovos com pouco vitelo apresentam estágio de náuplio geralmente de vida livre, ao contrário daquelas em que os ovos são ricos em vitelo, em que o estágio de náuplio sofre uma maior incubação. 
O desenvolvimento dos crustáceos pode ser do tipo direto, em que após a eclosão o jovem se assemelha ao adulto, como se fosse uma miniatura do mesmo; ou indireto, em que depois da eclosão surge uma forma larval característica que pode passar por vários estágios subsequentes até atingir a forma adulta. Brusca e Brusca (2007, p. 603-604) alertam de que os estágios de desenvolvimento dos crustáceos ainda é assunto controverso e ambíguo, pois não há um consenso científico dentre toda a diversidade existente no subfilo. Naqueles crustáceos que passam por desenvolvimento indireto, reconhecem-se cinco estágios, com nomes distintos: náuplio, metanáuplio, protozoé, zoé e pós-larva. O estágio de zoé é o que apresenta a maior diversidade de formas, levando autores a atribuir diversos nomes em grupos diferentes, como antizoé, misis, pseudozoé, acantossoma etc. Além disso, muitos estágios de desenvolvimento são cunhados por nomes distintos, dependendo da ordem na qual se inserem:

Por exemplo, os estágios modificados de zoé de estomatópodes são chamados de larvas antizoé e pseudozoé, e o estágio avançado de zoé de muitos malacóstracos é frequentemente chamados de larva misis. Em eufausiáceos, o náuplio é sucedido por dois estágios: caliptópis e furcília, que de certa forma correspondem aos estágios de protozoé e zoé, antes que a morfologia do adulto seja atingida (BRUSCA; BRUSCA, 2007, p. 604).

Assim, como até nos dias atuais o desenvolvimento dos crustáceos é assunto recorrente e de debates taxonômicos, no século XIX o tema também era objeto de estudos de outros naturalistas, alguns dos quais Müller se referia em seus artigos, como Van Beneden e Milne-Edwards. As diversas formas de desenvolvimento também eram conhecidas, conforme Müller aponta: 
"hoje sabemos que na maior parte dos crustáceos existe uma metamorfose, às vezes complicadíssima" (MÜLLER, 1892a, p. 125). Sua preocupaçáo em descrever o desenvolvimento dos crustáceos superiores e inferiores recorre às suas pesquisas no litoral de Desterro, que culminaram na publicação de Für Darwin.

No volume de 1892 (MÜLLER, 1892a), o autor publica: Trichodactylus, siri de água doce, sem metamorphose. Apesar de Müller nomeá-lo genericamente como "siri", atualmente este termo é destinado apenas aos crustáceos da família Portunidae. Trichodactylus se insere na família Trichodactylidae, encontrada em todo o Brasil, em córregos e riachos de água corrente e é popularmente conhecido como caranguejo de água doce.

Siris e caranguejos possuem diferenças morfológicas, sendo que uma das mais evidentes está no formato das patas traseiras, que nos caranguejos são pontiagudas e nos siris achatadas e amplas. Além disso, os siris (Portunidae) são exclusivamente marinhos, contrariando o habitat das espécies de Müller (água doce).

$\mathrm{O}$ autor não indica em qual espécie ele insere os organismos observados:

Sinto não poder indicar o nome da espécie a que se referem as minhas observaçôes. Parece haver por aqui duas espécies distintas de Trichodactylus, das quais uma vive nos ribeirinhos menores e a outra no Rio Itajahy e seus afluentes maiores (MÜLLER, 1892a, p. 126).

Porém sua preocupação central é resolver a seguinte questão:

Qual será, pois, o desenvolvimento dos siris de água doce? Debalde procurei por muitos anos a resposta a esta interessante pergunta, até que há pouco tive a satisfação de obter de um ribeirinho afluente do Rio Itajahy, uma fêmea de 
siri (do gênero Trichodactylus ${ }^{95}$ ) carregada de ovos. Logo à primeira vista o volume insólito dos ovos mostrou que os filhinhos deviam desenvolver-se dentro dos ovos muito além do estado de zoea, e com efeito, quando no fim de algumas semanas nasceram, eles se mostraram táo semelhantes a seus pais, que até exibiam quase todos os caracteres distintivos do gênero a que pertencem; eles nascem não só como siris, mas até como verdadeiros Trichodactylus (MÜLLER, 1892a, p. 125-126).

Ele já possuía conhecimento que os siris da família Brachyura (atual infra-ordem, no qual se inserem os Trichodactylus) passavam por estágios diversos de metamorfose, sendo que os marinhos nasciam como zoeas e não como siris. Comenta também que na época já se tinha conhecimento de uma espécie terrestre da família, que não passava por metamorfose; e buscou com sua observação dos representantes de água doce demonstrar que estes também não passavam por metamorfose, ao contrário de seus "parentes" (conforme original) marinhos (MÜLLER, 1892a, p. 125).

Essa observação do autor referente à ausência de desenvolvimento larval após eclosão do ovo, é o que se designa como desenvolvimento direto ou epimórfico, resultado de um retardamento na eclosão do embrião, o que causa a supressão ou ausência de náuplio (e de outro qualquer estágio larval) (BRUSCA; BRUSCA, 2007, p. 603). Tal condição é encontrada exclusivamente nos caranguejos de água doce, visto que estes incubam seus embrióes e independem da água salgada, ao contrário dos caranguejos terrestres, que ainda são dependentes do oceano para reprodução e desenvolvimento larval (BRUSCA; BRUSCA, 2007, p. 552).

95 Trichodactylus compóe uma família nos dias atuais. 
Após observar que os imaturos já nasciam como adultos, Müller realiza uma descrição minuciosa destes, começando pelo número de ovos, coloração e diâmetro, olhos, antenas anteriores e posteriores, mandíbulas, maxilas anteriores e posteriores, maxilípedes anteriores intermédios e posteriores, segmentos torácicos, pernas ambulatórias e abdômen; e após análise, discorda sobre as diferenças entre "filhotes" (conforme original) e adultos, descritas por Milne-Edwards (1800-1885) em sua obra Histoire naturelle de crustacés; de acordo com ele, o "célebre professor de Paris",

[...] não se conhecendo nos mares da Europa espécie alguma de siri, que como tal nascesse, é impossível que Milne Edwards tenha jamais examinado siri algum "au moment de la naissance” ${ }^{\prime 6}$ (MÜLLER, 1892a, p. 131-132).

No final do artigo ele recomenda aos naturalistas brasileiros que iniciem mais estudos referentes à metamorfose das diversas espécies de siris de água doce, para buscar comprovar se estes, de fato, conservam ainda parte ou integralmente a metamorfose a que foram submetidos seus ancestrais e que ainda é preservada nos exemplares marinhos, mas que não foi encontrada em seu exemplar (MÜLLER, 1892a, p. 132).

No artigo $O$ camarão miúdo do Itajahy, Atyoida potimirim (atual Potimirim potimirim, Müller), Müller se concentra em descrever a morfologia do camarão, bem como curiosidades sobre o comportamento alimentar da espécie e a limpeza realizada pelos indivíduos em seu corpo e nas brânquias (MÜLLER, 1892b).

O gênero Potimirim é inserido na família Atydae. No Brasil há três espécies: Potimirim brasiliana, encontrada nos estados de São

${ }_{96}$ No momento do nascimento. 
Paulo e Rio de Janeiro, Potimirim glabra, da região Norte até o estado de Santa Catarina, e Potimirim potimirim, descoberta por Müller em 1892, com registros de ocorrência também no estado de São Paulo, Pernambuco, Rio de Janeiro e Bahia ${ }^{97}$ (MATTOS; OSHIRO, 2009).

Quando ao epíteto potimirim, Müller elegeu tal nomeação por ser o menor camarão que já encontrou no Rio Itajahy, tomando emprestado a palavra do tupi-guarani, em que "poti” é camarão e "mirim", pequeno.

No início do artigo, o autor faz uma breve discussão sobre o estabelecimento do gênero Atya, Leach para camaróes encontrados no México, que possuíam como caracteres distintivos os três últimos pares de pernas muito grossos. Mais tarde, Randall $(1813-1892)^{98}$ observou uma espécie semelhante que possuía as pernas finas, estabelecendo o gênero Atoyda, no qual Müller também insere seu caranguejo pela mesma razão.

Um ponto interessante a ser comentado é a circulação das informações científicas pelas correspondências entre naturalistas, conforme já discutido. Müller fornece a referência à publicação de Randall e acrescenta: "Não pude consultar o trabalho de Randall; a sua diagnose do gênero Atyoida me foi comunicada pelos srs. Paul Mayer, da Estação Zoológica de Nápoles e Walter

97 O gênero Potimirim e suas diversas espécies ofereciam dúvidas taxonômicas quanto a formarem grupos monofiléticos ou não. Torati e Mantelatto (2012), após análise do DNA mitocondrial distinguiram que Potimirim potimirim e Potimirim mexicana são, de fato, espécies diferentes de acordo com os dados moleculares obtidos, bem como com análise da morfologia do apêndice masculino. Os autores ainda descobriram três espécies distintas sob o nome de Potimirim glabra recomendando então a aplicação do nome $P$. glabra para as populações da costa do Pacífico da América Central e revalidação de $P$. brasiliana para as brasileiras. Os autores utilizam em sua discussão uma das proposiçóes de Müller, em que a ontogenia do apêndice masculino recapitulou a filogenia proposta, oferecendo maior suporte.

98 Referência ao naturalista e poeta John Witt Randall, que estudou crustáceos na costa oeste dos Estados Unidos e Havaí. 
Faxon, do Museu de Zoologia Comparada de Cambridge (Massachussetts), aos quais me confesso muito agradecido por esse favor" (MÜLLER, 1892b, p. 156).

Outro fato observado pelo naturalista se refere à capacidade dos camarôes de mudarem de cor, dependendo do ambiente em que se encontram, conforme o excerto:

Entre plantas mortas os camaróes tomam a cor parda escura das mesmas plantas, faltando a listra dorsal; uma tarde pus em um vidro, em que já havia algumas dúzias de camarôes verdes, um destes camarôes pardo-escuros; já no fim de poucos minutos não o pude distinguir por ter tomado a cor esverdeada e a listra dorsal pardo-clara dos outros (MÜLLER: 1892b, p. 156).

Tal comportamento observado pelo autor é comum em diversos crustáceos devido à ação de hormônios antagônicos, denominados de $\mathrm{PCH}$ (cromatoforotropina agregadora de pigmento) e PDH (cromatoforotropina dispersora de pigmento). $\mathrm{O} \mathrm{PCH}$ é responsável por agregar melanóforos e eritróforos, levando ao clareamento do animal; enquanto $\mathrm{PDH}$ induz a dispersão desses pigmentos, levando ao escurecimento. A secreção desses hormônios está relacionada à influência ambiental, luminosidade e cor do ambiente. Camaróes utilizam a mudança de cor como estratégia de camuflagem a fim de se afugentar de predadores ou a terem o menor gasto energético durante a alimentação (CABRITA, 2012).

Outro fato se refere às pinças (mãos no original), as quais ele observou que nos machos eram muito menores do que nas fêmeas, e que não serviam de armas para combates com outros machos (MÜLLER, 1892b, p. 174) e também não serviam para agarrar e segurar a fêmea (MÜLLER, 1892b, p. 175). Mais uma vez, o autor estuda as diferenças sexuais dos machos, conforme já 
havia feito em Für Darwin e aplicando o princípio da seleçáo natural, que favorecia os machos com outras "armas de combate":

Não é pois, de se admirar, que se tenha desenvolvido no sexo masculino outros instrumentos, que possam substituir as mãos naquela função, como sejam o espinho curvo na ponta dos maxilípedes externos e o espinho basilar e tubérculos circunvizinhos nas tíbias dos pares terceiro e quarto das pernas torácicas, instrumentos que faltam aos machos de outras espécies, que podem servir-se de suas pinças para o dito fim (MÜLLER, 1892b, p. 175).

No artigo O camarão preto ${ }^{99}$, Palaemon potiuna ${ }^{100}$, Müller (1892c) trata da descrição da espécie, comum até os dias atuais nas bacias dos estados meridionais do Brasil, desde o Espírito Santo até o Rio Grande do Sul. Sáo conhecidos popularmente como camarôes de água doce ou pitus, e estão incluídos na família Palaemonidae, que compreende quatro subfamílias: Typhlocaridinae, Pontoniinae, Euryhynchinae e Palaemoninae. Em Palaemoninae, na qual se insere Palaemon potiuna, sáo conhecidos sete gêneros e 29 espécies para o Brasil, incluídas as espécies marinhas (BOND-BUCKUP, BUCKUP, 1989). De acordo Bond-buckup e Buckup (1989), em levantamento sobre os Palaemonidae de águas continentais do Brasil meridional, atribui-se o início dos estudos sobre os camaróes de água doce do sul do Brasil a Müller, que, além da espécie em questáo, descreveu: Palaemon potiporanga (Macrobrachium olfersi Müller) e Leander

\footnotetext{
99 Os machos adultos apresentam o corpo e pereiópodos escuros, por isso o vulgo "camarão preto". Jovens e adultos, quando vivos, apresentam cor amarelo pálida (CABRITA, 2012).

100 Atual Macrobrachium potiuna Müller. Está incluído na subfamília Palaemoninae, da família Palaemonidae (Decapoda: Caridea). No Brasil, o gênero está representado por 19 espécies (RAMOS-PORTO, COELHO 1998).
} 
potitinga (Palaemon pandaliformis Müller) todas encontradas em tributários do Rio ltajaí, em Blumenau.

Diversos estudos já foram realizados para a espécie, exemplo de Müller e Carpes (1991) sobre aspectos do ciclo reprodutivo, relacionando-o com parâmetros ambientais; Calluf (1997) e Nagata (2008) sobre a estrutura populacional da espécie no litoral do Paraná; e Mattos e Oshiro (2009) que também analisaram a estrutura populacional, porém no município de Mangaratiba, estado do Rio de Janeiro.

Müller descreve os camarôes encontrados em córregos tributários do Rio Itajaí, estudando adultos e também a metamorfose, fato este que chamou sua atenção desde o princípio das observaçóes, conforme o excerto:

Entre as espécies catarinenses de Palaemon há uma muito notável pela sua metamorfose inteiramente diferente da de todas as mais espécies deste gênero, e até da de todos os camarôes, cujo desenvolvimento se tem estudado até hoje. Ela oferece o exemplo mais esquisito e frisante do que se tem chamado de metamorfose abreviada (MÜLLER, 1892c, p. 179).

Essa referência sobre a metamorfose é provavelmente a primeira sugestáo de desenvolvimento pós-embrionário em camaróes, tipo de metamorfose abreviada ou desprovida de forma larval, o chamado desenvolvimento direto. Apesar de Müller não ter se aprofundado no tema, diversos autores, décadas depois, buscaram elucidar esse tipo epimórfico de desenvolvimento embrionário (MORAES, 2012).

Outro ponto interessante do artigo é certa "provocação" de Müller aos naturalistas que buscavam apenas nomear novas espécies sem se preocuparem com uma descrição acurada e minuciosa: 
Para se poder apreciar bem as diferentes fases dessa metamorfose tâo singular, torna-se indispensável descrever primeiro o camaráo adulto, entrando em certas minudencias, de que não se ocupam os fabricantes de <espécies novas> (grifo no original) (MÜLLER, 1892c, p. 179).

Para não ser um "fabricante de espécies", Müller descreve na primeira parte de seu artigo os indivíduos adultos, fornecendo tabelas comparativas acerca do número de dentes dorsais e ventrais neles encontrados. Através das medidas e variaçôes no número de dentes, bem como no comprimento dos rostros, Müller considera que estes caracteres são o meio mais cômodo para distinguir espécies, contrariando a opiniāo de Walter Faxon no Bulletin of the Museum de Cambridge (FAXON, 1879, p. 320), conforme o excerto a seguir: "Portanto, aparecerá a loucura desses zoólogos, que tomaram a forma do rostro como um meio de distinguir espécies no grupo de Caridea"101; 102 .

A descrição de Müller se refere a toda a morfologia externa dos adultos. Ele descreve os olhos, antenas anteriores, mandíbulas, maxilas anteriores e posteriores, maxilípedes anteriores, posteriores e intermediários, pernas torácicas (pernas quelíferas) anteriores e posteriores, largura dos dedos, mãos e braços, pernas natatórias, número de sedas plumosas encontradas na superfície ventral do corpo do animal e cavidade auricular ${ }^{103}$.

Todas essas descrições são comparadas com outras espécies do gênero, como Palaemon antennarius Milne-Edwards,

101 Caridea é o nome dado à infraordem na qual se insere o camarão.

102 Do original: hence will appear the folly of those zoologists, who have taken the form of the rostrum as a mean of distinguishing species in the group of Caridea. O boletim pode ser encontrado em formato eletrônico em: https://archive.org/stream/mobot31753003645972/mobot31753003645972_djvu.txt,. Acesso em: 20 jun. 2014. $103 \mathrm{Na}$ cavidade auricular, Müller encontrou otólitos (concreçóes de carbonato de cálcio $\mathrm{CaCO}_{3}$ ), presentes dentro de câmaras no aparelho vestibular. 
Palaemon potieté (atual Macrobrachium acanthurus Wiegmann), Palaemon potiporanga (atual Macrobrachium olfersi Wiegmann), Palaemon treillianus Milne-Edwards, Palaemonetes vulgaris Say e Palaemon jamaicensis Bouvier, encontradas nos trabalhos e ilustrações de naturalistas que pesquisavam crustáceos, como Walter Faxon, Milne Edwards, Heller e Spence Bate.

É possível encontrar (MÜLLER, 1892c, p. 187) a descrição das pernas torácicas do segundo par (ou pernas quelíferas anteriores), que mostravam diferença significativa entre machos e fêmeas. Os machos possuíam tais pernas com dimensōes extraordinárias, às vezes até excedendo o tamanho do corpo, sendo que na borda interna dos dedos se desenvolviam tubérculos ou dentes, característica também observada por Milne Edwards para a espécie Palaemon jamaicensis.

Tanto Müller quanto Edwards consideravam que a presença desses "caracteres distintivos" náo aparecia em todos os machos da espécie; porém apenas em machos "velhos", contrariando a opinião de outro especialista, Bate, que afirmava que o caractere era exclusivo do grupo e portanto passível de se criar um novo gênero, a saber: Macrobrachium (do latim: grande braço).

Sabe-se que Müller estava errado quanto à característica distintiva, visto que "sua espécie" foi reclassificada tempos depois conforme a proposição de Bate. Seu comentário acerca de Bate é um tanto áspero e pela forma com que se expressa, provavelmente Bate seja o anônimo citado como "fabricante de espécies novas"

Cumpre notar que esses caracteres distintivos do sexo masculino só se desenvolvem nos machos muito velhos, como já notou Milne Edwards no Palaemon jamaicanensis. Esta circunstância por si só basta para mostrar a inadmissibilidade do gênero Macrobrachium criado por Spence Bate, cujo 
único caracter distintivo é o desenvolvimento <imenso $>$ do segundo par de pernas torácicas <mais compridas do que todo o animal, desde a ponta do rostro até o extremo da cauda (MÜLLER, 1892c, p. 193).

Fica evidente o lado poético de Müller, sobretudo na descrição da espécie:

Os filhos do Palaemon potiuna nascem com o hábito geral dos camarôes; correm desde o princípio com os seus pais no fundo das águas, dando saltos enormes para cima ou para trás, quando assustados (MÜLLER, 1892c, p. 194).

Há ainda na descrição do animal adulto uma referência ao princípio de seleção natural de Darwin. Comparando os ovos de diferentes espécies do mesmo gênero, Müller observou o seguinte comportamento: quanto maior a fêmea, maior o número de ovos incubados ${ }^{104}$. Tal comportamento não se repetia em Palaemon potiuna: em suas "contagens", raramente encontrou mais de 20 ovos. Para ele, este fato poderia ser explicado pela seleção natural, uma vez que a proteção dos ovos era muito melhor em Palaemon potiuna, e por tal razão o número era limitado e muito menor se comparado com as congêneres.

Não se pode esquecer de que Müller era um ótimo matemático, o que o levou anos antes a ocupar o cargo de professor de matemática do Liceu Provincial de Desterro. Para estimar 75.000 ovos, realizou o seguinte cálculo:

104 "Em uma fêmea de Palaemon potiporanga, de $35 \mathrm{~mm}$ de comprimento contei perto de 1.200; são muito mais numerosos no Palaemon potieté; e em uma fêmea de Palaemon jaimaicensis de $14 \mathrm{~cm}$ de comprimento, calculei o seu número em mais de 75.000" (MÜLLER, 1892c, p. 183). 
Meti os ovos removidos do abdômen do camarão em um cilindro de vidro, onde eles ocupavam $9420 \mathrm{~mm}^{3}$. O eixo maior dos ovos elipsoidais era de 0,6 e o menor de $0,45 \mathrm{~mm}$; era, pois, o volume do paralelepípedo retângulo circunscrito ao ovo $0,6 \mathrm{X} 0,45 \mathrm{X} 0,45=0,1215 \mathrm{~mm}^{3}$. Dividindo por este número o volume ocupado pelos ovos resulta o quociente de 77531. Dividi pelo volume do paralelepípedo circunscrito e não pelo dos ovos por causa das lacunas que entre estes ficam (MÜLLER, 1892c, p. 183).

$\mathrm{Na}$ segunda parte do artigo, a "metamorphose dos filhos", inicia retomando a questão dos ovos para os crustáceos que passam pelo estágio de zoea e nos quais observou uma proporção em relação ao tamanho da fêmea e a quantidade de ovos. Ora, se essa proporção valesse para Palaemon potiuna as fêmeas teriam cerca de 600 a 1.200 ovos, porém em geral, produzem no máximo $29^{105}$ (MÜLLER, 1892c, p. 193). Müller notou que os ovos da espécie também aumentaram em volume em relação às congêneres, visto que em outras espécies coletadas do Rio Itajaí observou que os ovos mediam em comprimento entre 0,6 e 0,7 mm, e no diâmetro da seção transversal de 0,4 a $0,5 \mathrm{~mm}$. Em Palaemon potiuna as dimensóes aumentavam em $2 \mathrm{~mm}$ no comprimento e 1,5 mm no diâmetro (MÜLLER, $1892 c$, p. 193).

Essa característica leva Müller a supor que o aumento no tamanho dos ovos corresponderia a um maior tempo que o estado de zoea passaria dentro do ovo:

Essas dimensôes tão excepcionais podiam servir de indício quase infalível de que os filhos do camaráo preto dos nossos córregos, como os do siri (Trichodactylus), que nos mesmos córregos vivem, deviam dentro dos ovos

105 Em oito fêmeas Müller encontrou “8, 12, 16, 18, 19, 20, 21 e 29” ovos, levando uma média de 18 ovos por fêmea (MÜLLER, 1892c). 
passar muito além do estado de zoea, em que nascem os seus parentes do Rio Itajahy. E assim realmente acontece (MÜLLER:1892c, p. 193).

Essa metamorfose abreviada é explicada pela seleção natural, conforme o excerto a seguir:

Limito-me por hoje a fazer ver quanto não devem ter sido proveitosos no Palaemon potiuna as mudanças recentes de sua metamorfose. Se os filhos dos camarôes pretos nascessem como zoeas, semelhantes às de seus parentes do Rio Itajahy e das espécies marinhas, depois de qualquer temporal eles seriam esmagados pelas águas, que furiosas se despencam nos leitos íngremes dos córregos, habitados pelos ditos camaróes. Para nestes córregos poderem medrar, era necessário que seus filhos soubessem desde o princípio esconder-se e agarrar-se na ocasiáo das enchentes, ou então que o estado de zoea durasse só muito pouco tempo, para haver probabilidade de passar em enxurrada. Ora em breve tempo, ou, para melhor dizer, em tempo que não produziu modificação profunda nos animais adultos, a seleção natural conseguiu uma e outra coisa. Os maxilípedes intermediários e posteriores, que são os que servem à locomoção dos zoea dos camaróes, tem os seus ramos internos transformados em pernas ambulatórias, armadas no primeiro período da vida de unhas muito fortes, e dentro do curto prazo de 4 dias está concluída toda a metamorfose (MÜLLER: 1892c, p. 204-205).

Já em seu último artigo sobre crustáceos em Archivos, Descripção da Janira exul ${ }^{106}$, crustáceo isópode do Estado de Santa

106 Castro e Lima (1977), com base em exemplares coletados no estado de São Paulo nomeiam o gênero para Fritzianira. Bowmann et al. (1987) incluem Fritzianira como subgênero e elegem para a espécie o gênero Heterias, atualmente Heterias exul Müller. O epíteto exul, (exílio) utilizado por Müller, refere-se a este atributo da espécie de viver fora do mar, "pátria de seus avós e seus parentes", conforme ele 
Catharina (MÜLLER, 1892d, p. 207-220), Müller nomeia esta nova espécie de isópode de água doce. Para a descrição, utilizou como material de referência e de comparação as ilustraçôes, descriçôes e chave taxonômica de Oscar Harger, encontrados em Report on the marine Isopoda of New England (HARGER, 1878), comparando as espécies da Nova Inglaterra (regiāo dos Estados Unidos, localizada na porção nordeste do país) com a espécie brasileira.

A inserção no gênero, de acordo com o autor, surgiu a partir da observação de que os pares de antenas e o primeiro par de pernas torácicas mostravam-se semelhantes aos já descritos para o gênero Iaera, enquanto que os urópodes ${ }^{107}$ desenvolvidos (distintos no gênero citado) pareciam assemelhar-se a indivíduos do gênero Janira. Nesse sentido, inclui sua espécie no gênero Janira, "preferindo este expediente à criação de um gênero novo" (MÜLLER, 1892d, p. 207), considerando a descrição da nova espécie, a partir de três proposiçôes:

a) por ser, pelo que sei, o primeiro crustáceo isópode achado na água doce do Brasil;

b) por pertencer a um grupo de gêneros (Iaera, Janira, Munna) cujas espécies até hoje descritas vivem todas no mar;

c) pela configuração singular dos órgãos genitais no sexo masculino (MÜLLER, 1892d, p. 207).

Após consulta em banco de dados taxonômicos não se encontrou correspondências ao gênero Iaera citado pelo autor, supondo se tratar novamente de erro na grafia do texto publicado. Provavelmente Müller se refere ao gênero de isópodes Jaera.

mesmo esclarece (MÜLLER, 1892d, p. 207).

107 Urópodes é o nome dado ao último par de apêndices abdominais que é voltado para trás (BRUSCA; BRUSCA, 2007). 
A partir destas consideraçôes, descreveu a espécie catarinense comparando-a com as já descritas e ilustradas por Harger.

$\mathrm{Na}$ época, o gênero Janira estava inserido na família dos Asellideos, enquanto os gêneros Munnopsis e Eurycope estavam na família dos Munnopsideos. Para Müller esta não era uma decisão acertada, visto que todos estes gêneros deveriam ser incluídos na mesma família, conforme comenta: "Entretanto, como a descrição de uma nova espécie não é o lugar mais próprio para se discutir princípios de classificação, limito-me simplesmente a exprimir esta minha opiniáo sem entrar em pormenores" (MÜLLER, 1892d, p. 218).

Atualmente, os três gêneros estão incluídos na superfamília Janiroidea da ordem Isoposa, sendo que Munnopsis e Eurycope se inserem na família Munnopsidae, e Heterias (anterior Janira) na família Janiridae. 
Não me venham com conclusões!

A única conclusão é morrer.

Álvaro de Campos 